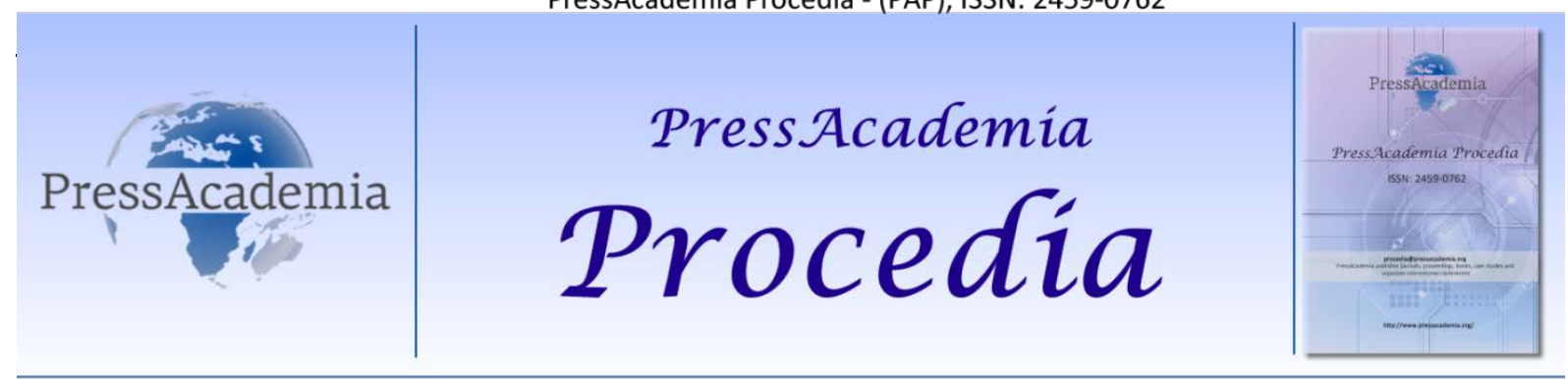

Global Business Research Congress (GBRC), May 26-27, 2016, Istanbul, Turkey.

\title{
LOGISTICS SECTOR IN TURKEY AND LOGISTICS VILLAGES
}

\section{DOI: 10.17261/Pressacademia.2016118643}

\author{
Nuray Terzi ${ }^{1}$, Ozlem Bolukbas ${ }^{2}$ \\ ${ }^{1}$ Marmara University. nurayterzi@marmara.edu.tr \\ ${ }^{2}$ Marmara University. ozlembolukbas87@hotmail.com
}

\begin{abstract}
Globalization in every sense we live in today's condition when logistics is a basic process for all existing organization, it is on important performance values. The country's existing logistics sector is constantly growing. This growth is positively related to the economy of the country. While Turkey is the seventeenth largest economy, our foreign trade is increased. In paralel to this our logistics markets's potential has been one hundred and twenty billion dollars. With this work, it is aimed to show the improvement of Turkey's logistics and to examine of contributions if which are made by the logistics village to this sector. By making swot analysis of the logistics sector's and logistics villages' in Turkey it is aimed to represent the positive effects of the current situation on economy. Results show that the promotion of logistics villages will contribute to both the growth of logistics sector and the economy.
\end{abstract}

Keywords: Logistics sector in Turkey, logistics villages in Turkey, logistics villages in the world, logistics sector, logistics villages.

JEL Codes: O40, L10, L80

\section{TÜRKIYE'DE LOJISTIK SEKTÖRÜ VE LOJISTIK KÖYLER}

\section{ÖZET}

Küreselleşmeyi her anlamda yaşadığımız günümüz şartlarında, lojistik; var olan tüm organizasyonlar için temel bir süreç iken ve firmaların performans değerlerini etkilemede önemli bir faktördür. Ülkedeki mevcut lojistik sektörü sürekli büyümektedir. Bu büyüme ile ülke ekonomisi doğru orantılıdır. Türkiye dünyadaki en büyük on yedinci ekonomi olurken, dış ticaretimiz artmış buna paralel olarak lojistiğin pazar potansiyeli yüz yirmi milyar dolar olmuştur. Bu çalışma ile, lojistiğin Türkiye'deki gelişimini göstermek ve lojistik köylerin lojistik sektörüne yapmış olduğu katkıları incelemek amaçlanmıştır. Türkiye'deki lojistik sektörün ve lojistik köylerin swot analizi yapılarak, mevcut durumu ve ekonomi üzerindeki olumlu etkisi ortaya konulmaya çalışılmıştır. Sonuçlar, lojistik köylerin yaygınlaştırılmasının hem lojistik sektörün hem de ekonominin büyümesinde faydalı olacağını göstemektedir.

Anahtar Kelimeler: Türkiye'de lojistik sektörü, Türkiye'de lojistik köyler, Dünya'da lojistik köyler, lojistik sektörü, lojistik köyler. JEL Kodları: O40, L10, L80.

\section{GíRiş}

Dünyada ticaretin küreselleşmesi ve serbestleşmesiyle birlikte ticaret hacmi büyümüştür. Büyüyen bu hacim uluslararası ticarete farklı boyutlar kazandırmıştır ve her ülke bu pastadan payını almak ister hale gelmiştir. Rekabet ise, öne çıkan unsur olmuştur. Ülkeler bu rekabet ortamında bir adım daha ileri gidebilmek için lojistik sektörünün önemini fark etmiş ve lojistik sektörüne yatırımlar yapmaya başlamışlardır. Lojistiğin önemi ilk Amerika'da fark edilse de, Avrupa'lı ülkeler lojistikte daha ileri gitmişlerdir.

Türkiye'de lojistik sektörü, Avrupa ile kıyaslandığında geridedir. Ülkemizde son 50 yıl içinde var olan bir olgudur. Sürekli gelişme kaydeden bu olgu ile ülkemizde lojistik faaliyetler önemsenmiş, devlet tarafından yatırımlar 
yapılmış, lojistik köyler kurulmuş ve Türkiye'nin dünya çapında bir lojistik üs olması hedeflenmiştir. Türkiye, sahip olduğu coğrafi konumu sayesinde stratejik öneme ve avantaja sahiptir. Bu avantajı kullanarak ülkemizde lojistik sektörünün gelişmesi ve dünyada hatırı sayılır bir yere gelinmesi çok yakındır. Hükümetçe lojistik, 2023 Hedefleri doğrultusunda öne çıkarılmış sektörlerdendir. Özellikle lojistik köy uygulamaları üzerine yoğunlaşılmış, bazıları kurulmuş bazıları yapı ve ihale aşamasındadır.

Lojistik köyler, farklı taşıma türlerinin bir arada kullanıldığı, lojistik operasyonların tek elden yürütüldüğü, ihtiyaç duyulan her sistemin ve hizmetin bulunduğu entegre olmuş kuruluşlardır. Lojistik köyler sayesinde; zaman, masraf, bürokratik süreç, vb. sorunların büyük ölçüde önüne geçilebilmektedir. Dünya'daki lojistik köylere baktığımızda; İtalya, Almanya, İspanya ve Fransa öne çıkan ülkelerdendir. Türkiye'de ise 7 lojistik köy faaliyete geçmiştir. Bu lojistik köylerle TCDD, lojistik alanında sıçrama yapmak istemektedir. Köylerin faaliyete geçmesiyle taşınan toplam yükte \%50 artış beklendiği gibi, ekonomik anlamda da aynı oranda bir artış beklenmektedir.

Bu çalışmada; lojistik kavramı ve süreci hakkında genel bilgi verilecektir. Lojistik köyler hakkında genel bilgiler verildikten sonra Dünya'daki ve Türkiye'deki lojistik sektörü incelenecektir. Türkiye'deki lojistik köylerin, lojistik sektörüne ve ekonomiye katkısı verildikten sonra, Dünya'da ve Türkiye'de lojistik köylerin incelemesi yapılacaktır. Türkiye'deki faaliyete geçmiş lojistik köylerden bazıları ayrıntılı açıklanarak, swot(gzft) analizi yapılacaktır. Ayrıca, Türkiye'deki ve Dünya'daki lojistik köyler karşılaştırılarak, Türkiye'de bulunan lojistik köylerdeki standart ve kalite düzeyi hakkında bilgi verilecektir.

\section{LITERATÜR TARAMASI}

\subsection{Lojistikle İlgili Genel Bilgiler}

Kelime olarak lojistik, Yunanca "Logistikos" kelimesinden gelmektedir, "hesap kitap yapma bilimi”, "hesapta beceriklilik" anlamına gelmektedir. Lojistik kelimesi ilk olarak Silahlı Kuvvetlerde kullanılmıştır(Tanyaş, 2004). Lojistik birçok faklı sektörde kullanıldığından dolayı farklı tanımları vardır;

Dış ticaret kapsamında lojistik ise, belirli bir bedel karşılığında müşterilerin ihtiyaçlarını karşılamaya yönelik olarak nihai bir ürünün ihracatçı ülkedeki üretim yerinden, ithalatçı ülkedeki tüketim noktasına ulaştırılmasını sağlayan tüm faaliyetler ve bunların yönetimi seklinde ifade edilmektedir(Canıtez ve Tümer, 2005: 153).

Lojistiğin 7 Doğrusu (Seven Rights)'na göre; Doğru ürünü,doğru müşterinin, doğru yerine, doğru zamanda, doğru miktarda, doğru şekilde, doğru maliyette, teslim etmek önemlidir (Tanyaş ve Hazır, 2011: 7).

Lojistiğin amacl; işletmede meydana gelen tüm lojistik faaliyetleri minimum maliyetle, etkin ve verimliliği maksimize ederek müşteri memnuniyetini sağlamaktır ve bunun başarılı bir biçimde yerine getirilmesidir (Timur, 1988: 9)

Lojistiğin Temel Faaliyetleri; Aslında yapılan bu faaliyetler genellendirilemez çünkü her firmanın amaçları ve planları ölçüsünde sıraladığımız bu faaliyetler değişkenlik gösterebilir. Firmalarda çoğunlukla uygulanan faaliyetler; müşteri hizmetleri, taşımacılık, sigorta, envanter yönetimi, talep tahmini sipariş işleme, gümrük hizmetleri, depolama ve dağıtım, satın alma, yer(tesis) seçimi, elleçleme, tersine lojistik (reverse logistics- rl), üçüncü ve dördüncü parti lojistik (3pl, 4pl).

\subsection{DÜNYA'DA LOJISTIK SEKTÖRÜ}

\section{Dünya Lojistik Sektörü}

Hizmetler sektörü ticarete konu olan alanlarda ekonominin rekabet gücünün korunması ve geliştirilmesi açısından önemli bir rol oynamaktadır. Bu çerçevede, ulaştırma ve lojistik gibi kritik hizmet sektörlerinin yüksek büyüme ortamının getireceği büyük ölçekli ürün ve hizmet arzını zamanında, etkin ve uygun maliyetle karşılayabilmesine yönelik bir dönüşümün gerçekleştirilmesi gerekmektedir (D.A.K.A, 2014: 5).

Küresel ekonomi ile lojistik doğru orantılıdır. 2008 yılındaki 16.159.000 milyon dolarlık ihracat hacmi 2009 yılında \% 22'lik bir düşüş yaşayarak 12.554 .000 milyon dolara gerilemiştir. Bununla beraber ithalat verilerine baktığımızda da neredeyse aynı oranda bir kırılmadan bahsetmek mümkündür. 2008 yılında 16.572 .000 milyon 
dolarlık dünya ithalat hacmi 2009 yılına \% 30'luk bir gerileme yaşamış ve 12.781 .000 milyon dolar olmuştur (Yılmaz, 2015: 52).

DTÖ’nün Dünya ve Bölgesel ìhracat Raporu (Temmuz 2010) irdelendiğinde 2000'li yıllardan bu yana dünya genelinde ithalat artış hızının, ihracata göre daha yavaş bir seyir izlediği ve bunun da dış ticaret açıklarına yol açtığı gözlenmektedir. 2009 yılında yaşanan küresel kriz dünya ekonomisinde önemli bir daralmaya yol açmış, 2. Dünya Savaşı'ndan bu yana küresel daralma ilk kez \%2'yi geçmiş, dünya mal ticaret hacmi \%22,6, hizmet ticaret hacmi ise \%12,9 oranında azalmıştır. Kriz sebebi ile dünya piyasalarında meydana gelen düşüşler, dünya lojistik sektöründe de daralmalara neden olmuştur. Ayrıca lojistik açıdan inceleme yapıldığında ticari mal ihracatının ağırlıklı olarak Asya ve gelişmekte olan ülkelere kaydığı gözlenmektedir. Dünya'da lojistik, 2009 yılında 6 trilyon dolarlık bir pazar oluşturmuştur. 2015'te bu pazarın 10-12 trilyon dolarlık bir hacme çıkması beklenmektedir (TOBB, 2012: 1-2).

Dünyadaki lojistik sektörünün başını çeken ülkeler; ABD, İngiltere, Singapur, Japonya, Hollanda, Almanya, İsveç, Fransa'dır. Dünya lojistik pazarının yüzde elliden fazlasına sahip olan ABD ve Avrupa dışında, son dönemde, Dubai ve Hong Kong gibi şehirler de lojistik üs olma yolunda hızla ilerlemektedirler. Gelecekte önemi artacak bölgeler ise sırasıyla Asya-Pasifik, Doğu Avrupa, Rusya ve Ortadoğu olarak belirtilmektedir (Işıkhan, 2011: 81).

ABD Lojistik Sektörü: 16 Trilyon dolarlık ticaret hacmine sahip dünya ekonomik pazarında, lojistik hacim ortalama 6.4 trilyon dolar (\%40) civarında bulmaktadır. Küresel lojistik pazarlar Amerika, Avrupa ve Asya Pasifik'ten oluşan üç büyük bölgeden oluşmaktadır. Lojistik sektördeki yıllık büyüme oranları ise, gelişmiş ülkelerde \% 5-12 arasında seyrederken, gelişmekte olan ülkelerde ise bu oran \%15-25 çıkmaktadır (Kuzey Amerika da yıllık \%15). Gelişmiş ülkelerde lojistik kapasiteyi GSYiH'nın ortalama \%10-12'lik bölümü oluşturmaktadır. Gelişmekte olan ülkelerde ise \% 2-5 arasındadır. ${ }^{1}$ ABD, 17 trilyon dolar GSYiH ile dünyanın en büyük ekonomisine sahiptir, lojistik kapasitesi ise ortalama 1 trilyon 700 milyon dolardır.

$A B D$, dünyanın en geniş coğrafi alana sahip ülkelerinden bir tanesi olmasından dolayı, dağıtım ve tedarik zincirlerinde yer alan lojistik faaliyetler üretici firmalar açısından çok önemlidir. Bu ülkede faaliyet gösteren lojistik firmalarının temel hedefleri, müşterilerine kaliteli, hızlı, güvenilir ve esnek hizmet sunmaktır. Los Angeles, New York, Chicago, ayrıca Memphis, Lousville, ve Memphis ABD’deki önemli lojistik merkezlerdendir.

AB Lojistik Sektörü: AB'nin kurulmasıyla ortak gümrük tarifesine geçilmesi, bürokratik sorunların azalması, çok ülkeli Avrupa bölgesinde sınırların ortadan kalkması, ortak para biriminin kullanılması ile Avrupa içerisinde ticaret yapmak ve lojistik faaliyetler kolaylaşmıştır. SSCB(Sovyet Sosyalist Cumhuriyetler Birliği)'nin dağılmasıyla bloktan ayrılan on ülke $A B^{\prime}$ ye katılmıştır. $A B^{\prime}$ nin üye sayısı ve etkinlik alanı artmıştır. Son olarak Makedonya'nın Birlik'e katılmasıyla üye sayısı 28'e yükselmiştir. Avrupa Birliği ile, Avrupa'daki ticaret hacmi artmış, lojistik sektöründe olumlu yönde değişimler yaşanmıştır. Bunun sonucunda, $A B^{\prime}$ deki lojistik firma sayısı ve lojistiğe yapılan yatırımlar artmıştır. Ayrıca, AB içerisindeki ticareti kolaylaştırıcı etmenlerden dolayı bazı büyük Amerikan lojistik firmaları da bu sektörden pay alma çabasına girip özellikle Doğu Avrupa'ya yatırımlarda bulunmuştur.

Avrupa'da lojistik sektörü ağırıklı olarak, perakendecilik, otomotiv, ilaç ve tıbbi malzeme sektörleri üzerine kurulmuştur. Ayrıca doğu ile batı arasında önemli bir köprü görevi yapan Avrupa ülkeleri (Bulgaristan, İtalya, Polonya, İspanya, Belçika, Almanya vb.) önemli taşıma modlarına ve lojistik merkezlere sahiptirler. Örneğin, Polonya'da Poznan, İspanya'da Zaragoza ve Barcelona, İtalya'da Trieste, Bulgaristan'da Varna, Belçika'da Antwerp, Almanya'da Hamburg, Hollanda'da Rotterdam Avrupa'nın önde gelen lojistik üslerini bölgelerinde barındırmaktadır (Schacke, 2001: 16-20). Avrupa'daki Rotterdam Limanı ise AB'nin ve dünyanın hem en önemli hem de en büyük limanlarından biridir. Amsterdam Schipol Havalimanı AB'nin ve dünyanın önemli kargo havalimanlarından biridir. Almanya, yüksek ulaştırma yapısıyla lojistik sektöründe Avrupa'da önemli bir lojistik merkez olmuştur. Almanya'nın 9 Avrupa ülkesiyle olan sınırı, Almanya'yı ulaşım ağlarının merkezine taşımıştır. Diğer Avrupa ülkelerine göre demiryolu ağları ve karayollarında üstünlüğü vardır. Lojistik Almanya'daki ilk üç sektörden biridir. Rehn nehri önemli bir iç suyoludur.

\footnotetext{
${ }^{1}$ http://www.lojistikci.com/?p=3824
} 
Lojistik $A B^{\prime}$ nin yükselen yıldızı olurken, ileriki yıllarda $A B$ bölgesi içerisinde lojistik faaliyetler için ayrılan alanlar yetmeyecektir. Jones Lang LaSalle tarafından hazırlanan yeni bir rapora göre; Avrupalı perakendeciler önümüzdeki beş yıl içinde 25 milyon metrekare ek lojistik alan gerekecektir. Önümüzdeki beş yılın her biri için beş milyon metrekaredir. ${ }^{2}$

\section{Grafik 1: AB'de Ülke Başına Lojistik Pazar Büyüklüğü}

(2013 - 2017 arası tahmini milyon Euro)

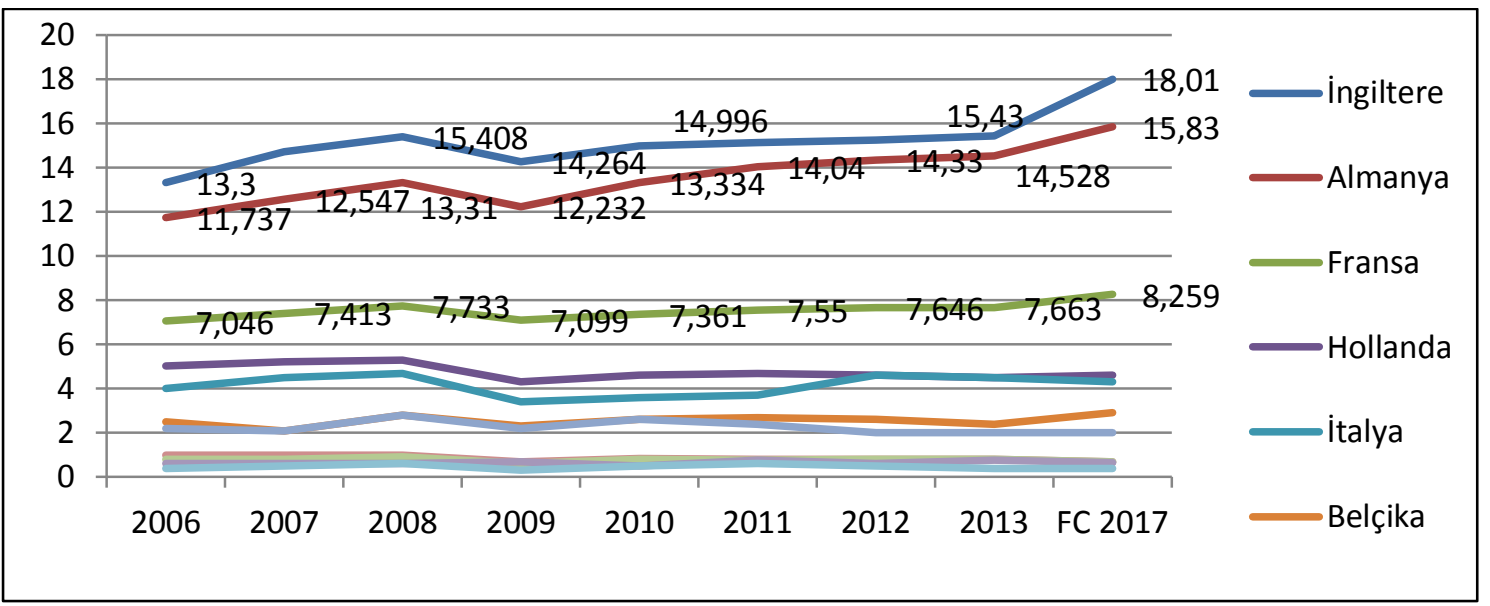

Kaynak: Global Logistics Markets, Barcalys, Roland Berger Strategy Consultants, Agust, 2014, s.12

Almanya ve İngiltere, Avrupa bölgesinin en büyük ekonomilerini oluşturmakla birlikte, Avrupa'daki lojistik sektör payının \% 50 sini ellerinde bulundurmaktadırlar. Büyük olasılıkla 2017 yılında da Almanya ve İngiltere liderlik rollerini sürdürecektir. 2008 krizinin olumsuz etkileri lojistik sektöründe de hissedilmektedir.

Uzakdoğu Lojistik Sektörü: Uzakdoğu’nun gelişmiş ekonomiye sahip ülkeleri; Hong Kong, Güney Kore, Singapur, Tayvan'dır. Ekonomisi gelişmekte olan ülkeler; Çin, Endonezya, Malezya, Filipinler ve Tayland'dır. Çin, Hindistan ve Endonezya kıtanın nüfusu en yüksek ülkeleridir. Kıtanın büyüklüğü ortalama 45 milyon km² dir.

Uzak doğunun büyüyen devi Çin'de ulaşım ve lojistik maliyetleri 2001 yılında 230 Milyar \$ olup Gayri Safi Yurt İçi Hasılanın \% 20'sini oluşturmaktadır(Baki, 2004) 2010 yılında küresel GSMH'nin \%17'sine denk bir gelire sahip olan Çin'de lojistik sektörünün ürettiği katma değer 450 milyar \$ olarak tahmin edilmektedir(AT Kearney, 2010: 2). Çin'de lojistik sektörü, doğuda okyanusa kıyısı olan sanayi kentlerinde yoğunlaşmıştır. Bu yoğunluğu ülke geneline yaymak isteyen Çin hükümeti daha iç bölgelere yatırımlar yapmaktadır. Pearl Nehri Deltası, Yangtze Deltası ve Bohai bölgesi olarak bilinen 3 merkezdeki kentler bu yatırımlarla lojistik sektörünün kümelendiği yeni merkezler olma yolunda ilerlemektedir(AT Kearney, 2010: 3).

Uluslararası Demiryolları Birliği (UIC) istatistiklerine göre 2009 yılında dünyadaki demiryolu ile toplam net taşıma miktarının yaklaşık yarısı Asya ve Okyanusya (Avustralya)'da gerçekleşmiştir. Demiryolu ağı güçlü ve geniş olan Avrupa'nın bunu ticarete yansıtamadığı görülmektedir.

ACl- AIRPORTS COUNCILS INTERNATIONAL'a göre 2013 yılında dünyada en çok kargo elleçlenen ilk 20 havaalanı içerisindeki Listedeki ilk 20 ülke arasında 8 Uzakdoğu limanı, 6 ABD limanı, 4 Avrupa limanı bulunmaktadır. Uzakdoğu ülkeleri dünyada en çok elleçleme yapılan havaalanlarına sahiptir. ${ }^{3}$

\section{Dünya Bankası Lojistik Performans Endeksi (LPI)}

Dünya Bankası Küresel Lojistik Performans Endeksi'nin 2014 versiyonu (Connecting to Complete 2014: Trade Logistics in the Global Economy) 21 Mart 2014'te yayınlandı. 2007 yılından beri, iki yılda bir yayınlanmakta olan

\footnotetext{
${ }^{2}$ http://europe-re.com/report/view/41782/a-new-logistics-real-estate-landscape-the-impact-of-multi-channel-retail-onlogistics-jll

${ }^{3}$ http://www.aci.aero/Data-Centre/Annual-Traffic-Data/Cargo/2013-final
} 
Lojistik Performans Endeksi, Dünya Bankası'nın Uluslararası Ticaret Birimi tarafından oluştururlan, dünya çapında 1000 'den fazla lojistik profesyonelinin katılımıyla oluşturulan bir rapor niteliği taşımaktadır. ${ }^{4}$ LPI'de $^{\prime}$ puanlama beş tam puan üzerinden hesaplanır ve böylece ülkelerin lojistik sektöründeki gelişmişlik düzeyi ölçülür. Raporda bu yıl değerlendirmeye alınan ülke sayısı 155'ten 160'a çıkarılmıştır. ${ }^{5}$

Tablo 1: Lojistik Performans Endeksi (World Bank, 2007, 2010, 2012, 2014)

\begin{tabular}{|c|c|c|c|c|c|c|c|c|c|c|c|}
\hline \multicolumn{3}{|c|}{2007 LPI } & \multicolumn{3}{|c|}{2010 LPI } & \multicolumn{3}{|c|}{2012 LPI } & \multicolumn{3}{|c|}{2014 LPI } \\
\hline Sıra & Ülke & $\begin{array}{l}\text { Pua } \\
n\end{array}$ & Sira & Ülke & Puan & Sira & Ülke & $\begin{array}{l}\text { Pua } \\
n\end{array}$ & Sira & Ülke & $\begin{array}{l}\text { Pua } \\
n\end{array}$ \\
\hline 1 & Singapur & $\begin{array}{l}4,1 \\
9\end{array}$ & 1 & Singapur & 4,13 & 1 & Almanya & $\begin{array}{l}4,1 \\
1\end{array}$ & 1 & Almanya & $\begin{array}{l}4,1 \\
2\end{array}$ \\
\hline 2 & Hollanda & $\begin{array}{l}4,1 \\
8\end{array}$ & 2 & Hong K. & 4,12 & 2 & Singapur & $\begin{array}{l}4,0 \\
9\end{array}$ & 2 & Hollanda & $\begin{array}{l}4,0 \\
5\end{array}$ \\
\hline 3 & Almanya & $\begin{array}{l}4,1 \\
0\end{array}$ & 3 & Finlandiya & 4,05 & 3 & İsveç & $\begin{array}{l}4,0 \\
8\end{array}$ & 3 & Belçika & $\begin{array}{l}4,0 \\
4\end{array}$ \\
\hline 4 & İsveç & $\begin{array}{l}4,0 \\
8\end{array}$ & 4 & Almanya & 4,03 & 4 & Hollanda & $\begin{array}{l}4,0 \\
7\end{array}$ & 4 & Ingiltere & $\begin{array}{l}4,0 \\
1\end{array}$ \\
\hline 5 & Avusturya & $\begin{array}{l}4,0 \\
6\end{array}$ & 5 & Hollanda & 4,02 & 5 & Lüksemburg & $\begin{array}{l}3,9 \\
8\end{array}$ & 5 & Singapur & $\begin{array}{l}4,0 \\
0\end{array}$ \\
\hline 6 & Japonya & $\begin{array}{l}4,0 \\
2\end{array}$ & 6 & Danimarka & 4,02 & 6 & İsviçre & $\begin{array}{l}3,9 \\
7\end{array}$ & 6 & İsveç & $\begin{array}{l}3,9 \\
6\end{array}$ \\
\hline 7 & İsviçre & $\begin{array}{l}4,0 \\
2\end{array}$ & 7 & Belçika & 3,98 & 7 & Japonya & $\begin{array}{l}3,9 \\
7\end{array}$ & 7 & Norveç & $\begin{array}{l}3,9 \\
6\end{array}$ \\
\hline 8 & Hong K. & $\begin{array}{l}4,0 \\
0\end{array}$ & 8 & Japonya & 3,93 & 8 & İngiltere & $\begin{array}{l}3,9 \\
5\end{array}$ & 8 & Lüksemburg & $\begin{array}{l}3,9 \\
5\end{array}$ \\
\hline 9 & İngiltere & $\begin{array}{l}3,9 \\
9\end{array}$ & 9 & A.B.D & 3,93 & 9 & Belçika & $\begin{array}{l}3,9 \\
4\end{array}$ & 9 & A.B.D. & $\begin{array}{l}3,9 \\
2\end{array}$ \\
\hline 10 & Kanada & $\begin{array}{l}3,9 \\
2\end{array}$ & 10 & İngiltere & 3,90 & 10 & Norveç & $\begin{array}{l}3,9 \\
3\end{array}$ & 10 & Japonya & $\begin{array}{l}3,9 \\
1\end{array}$ \\
\hline 34 & Türkiye & $\begin{array}{l}3,1 \\
5\end{array}$ & 39 & Türkiye & 3,22 & 27 & Türkiye & $\begin{array}{l}3.5 \\
1\end{array}$ & 30 & Türkiye & $\begin{array}{l}3,5 \\
0\end{array}$ \\
\hline 150 & Afganistan & $\begin{array}{l}1,2 \\
1\end{array}$ & 155 & Burundi & 1,61 & 155 & Somali & $\begin{array}{l}1,3 \\
4\end{array}$ & 160 & Somali & $\begin{array}{l}1,7 \\
7\end{array}$ \\
\hline
\end{tabular}

Kaynak: http://lpi.worldbank.org/report ( Erişim tarihi: 26.12.2015)

2007 ve 2010 yıllarında en yüksek puanla birinci Singapur olurken, 2012 ve 2014 yıllarındaki birinci Almanya'dır. Baz alınan bütün yıllarda ise özellikle ilk beşte Singapur, Almanya ve Hollanda'yı görmekteyiz. Bu üç ülke lojistik açıdan kendisini geliştirmiş; Singapur, Almanya, Hollanda lojistik merkez (üs) haline gelmiş ülkelerdir. Türkiye ise, yükselme eğilimindedir.

\subsection{Türkiye'de Lojistik Sektörü}

Türkiye lokasyon olarak Orta Doğu, Türk Cumhuriyetleri ve Avrupa arasında bir aktarma merkezi ve köprü oluşturmasından kaynaklanan avantajlı konumu ile birçok otorite tarafından lojistik üssü olma iddiası veya ideali

${ }^{4}$ http://www.und.org.tr

5 http://www.und.org.tr 
ile tanımlanmaktadır. Türkiye coğrafyasının lojistik bakış acısıyla önemli üstünlükleri vardır. Türkiye, dünya coğrafyası üzerindeki konumu, sahip olduğu genç ve dinamik nüfusu ve lojistik sektörüne verilen önem ve yatırımlar sayesinde lojistik sektöründe dünyada önemli bir lojistik üs konumuna gelebilecek bir potansiyele sahiptir(Acar ve Gürol, 2013: 291).

Türkiye'nin gerek stratejik gerekse politik açıdan bölgesinde sahip olduğu avantajlar olarak; coğrafi ve ekonomik bakımlardan Orta Doğu ve Hazar Petrollerine yakınlığı, doğal kaynak Kafkasya'yla olan bağlantıları ile ortak tarihsel ve kültürel geçmişi, Türk Cumhuriyetleri ile ilişkileri, yakın Akdeniz Bölgesi deniz ulaştırma yollarının kesişim noktasında bulunması, Karadeniz Bölgesi ve Boğazlar, AB ve Balkan ülkeleri ile olan entegrasyon çalışmaları ve Doğu - Batı ile Kuzey - Güney ekseninin kesişim noktasında bulunması sayılmaktadır(Erdal ve Çancı, 2012).

Ek olarak Asya, Avrupa ve Afrika kıtalarının ortasında yer almaktadır. Coğrafi konumunun olumlu etkilerinden dolayı ülkemizin lojistik merkez olabilme ihtimali artmaktadır. Lojistik üs olma yolunda bu kadar avantajı olan ülkemizin, Türkiye Odalar ve Borsalar Birliğinin 25 Aralık 2012 tarihli 6. Türkiye Sektörel Ekonomi Şurası raporunda Ulaştırma ve Lojistik Meclisi başlığında ele alınan en önemli sorun lojistik köyler için gerekli alt yapının oluşturulamamış olmasıdır(TOBB, 2012: 86).

Türkiye'de, 1980'li yıllardaki "nakliye-taşımacılık" anlayışından, 2000'li yıllarda "lojistik"e geçilmiştir. Lojistik, Türkiye'de beyaz eşya, hızlı tüketim maddeleri ve ilaç sanayileri ile gelişmeye başlamıştır. Otomotiv, tekstil, elektronik ve petrol ürünleri sanayilerinden gelen taleple de bugünkü konumuna gelmiştir(Dikmenli, 2008:86)

Türkiye genelinde gerçekleştirilen lojistik sürecin, döngünün ve işlemlerin tam olarak anlaşılabilmesi için dış ticaretle ilgili ekonomik verilerin incelenmesi gerekmektedir.

\section{Türkiye Ekonomisi}

Ülke ekonomisi ile lojistik sektörü doğru orantılıdır. Ülke ekonomisindeki her pozitif hareket lojistik sektörünü de olumlu şekilde etkileyecektir.

Türkiye'nin dış ticaretine dair yorum yapabilmek ve rakamlardaki gelişmeleri görebilmek için Türkiye i̇statistik Kurumu (TÜiK)'nun ve Gümrük Müsteşarlığı'nın birlikte hazırladığı dış ticaret raporuna göre, ülkemize ait dış ticaret verileri incelendiğinde; 2008 yılındaki ihracatımız 132 milyar ABD doları seviyesinde iken 2009 yılındaki kriz ile ihracatımız daralmış ve 100 milyar dolara kadar düşmüştür. Ihracatımızın ithalatı karşılama oranı artmıştır.

2014 yılında 2013 yılının tersine ithalatta daralma, ihracatta artış yönünde değişim gözlenmiştir. Yakın çevre ülkelerde yaşanan siyasi gelişmelere rağmen yurtiçi talebin zayıf seyretmesi ve döviz kurunda yaşanan gelişmeler sonucunda ihracat artmış, iç talepteki durgunluk ve alınan makro ihtiyati tedbirlerin etkisiyle ithalatta azalma gerçekleşmiştir. 2014 yılında ihracat, yurtiçi talebin zayıflığı ve kur artışları ile dış talep kaynaklı olarak \%3,8 artarak 151.803 milyon dolardan 157.642 milyon dolara yükselmiştir. 2014 yılında yurt içi talep koşullarının zayıf seyri, yıın ikinci yarısında petrol fiyatlarında kaydedilen hızlı düşüş ile 2012 ve 2013 yıllarında dış ticaret dengesi üzerinde önemli ölçüde etkili olan altın ticaretinin tarihsel değerlerinde seyretmesi ithalatın daralmasında etkili olmuştur. İthalat 2013 yılına göre \% 3,8 azalarak 251.661 milyon dolardan 242.183 milyon dolara gerilemiştir. Böylece, Türkiye'nin dış ticaret açığı 2014 yılında \%15,3 oranında daralarak 84.541 milyon dolara gerilemiştir. 2013 yılında \% 3,7 artış gösteren dış ticaret hacmi, 2014 yılında ihracattaki büyümeye karşın ithalattaki azalışın etkisi ile \% 0,9 azalarak 399.825 milyon dolar olmuştur (TOBB, 2014:127).

Türkiye'nin stratejik konumu; GSYIH'si toplam 27 trilyon ABD dolarına ulaşan ve 8 trilyon ABD doları ile dünyadaki toplam ticaretin neredeyse yarısına karşılık gelen bir dış ticaret değerine sahip birden fazla pazara erişim sağlamaktadır. Türkiye'deki ticaret dikkat çekici bir biçimde artmakta olup bölgenin küresel ticaretteki varlığı da giderek güçlenmektedir. 2014 yılında Türkiye'nin küresel ticaret hacmi içerisinde neredeyse \% 1,1 olan payının 2025 yılında kadar \% 1,5'i geçmesi beklenmektedir. ${ }^{6}$

\footnotetext{
${ }^{6}$ http://www.invest.gov.tr/tr-tr/sectors/Pages/TransportationAndLogistics.aspx
} 
Lojistik operasyonlarındaki ihracat rakamlarını sadece değer olarak düşünmek hatalıdır, çünkü ihracatı yaptığımız ülke, bu ülkenin siyasi konumu, ne çeşit taşıma türü ile yapıldığı, yapılan ihracatın toplam tonaj gibi kıstasları önemlidir.

Gerçekleştirilen lojistiğin nereye, ne miktarda yapıldığı kadar, ne tür taşıma yani hangi mod taşıma kullanılarak yapıldığı da önemlidir. Ülkemizdeki denizyolu taşımacılığı sürekli bir artış içindedir, bunda ülkemizin üç tarafının sularla çevrili olması önemlidir. Denizyoluyla daha fazla malı (ayrıca ebat olarak büyük) daha ekonomik taşımak mümkündür. Havayolları da gelişen teknolojiden faydalanmış ve taşımacılıkta da bunu yansıtmaya çalışmıştır. Fakat 2012-2013 yılları arasında ciddi bir düşüş yaşanmıştır. 2009 krizinin etkisi taşımacılık modlarının hepsinde görülmektedir. Itthalat modlarında demiryolu kullanım oranı diğer modlara göre oldukça düşüktür. İthalattaki denizyolu kullanım oranı ihracata göre fazladır. Taşımacılıkta en fazla kullanılan mod ( ihracat+ithalat) deniz yolu sonra kara yolu ve daha sonra hava yolu olmuştur.

\section{Türkiye Vizyonu Kapsamında Lojistik Stratejisi ve Sektörden Beklentiler}

Türkiye'nin artan ekonomik verimliliği ve küreselleşme sonucunda, firmaların uluslararası ortamda rekabet gücü kazanma isteği artmıştır. Bu durumun sonucu olarak da taşımacılık ve lojistik sektörleri büyümeye ve değer kazanmaya başlamıştır. Gerek gümrük vergilerini sıfıra indiren Gümrük Birliği Anlaşması çerçevesinde gerekse de Gümrük ve Ticaret Bakanlığı tarafından oluşturulan ve yerli üreticinin dış pazardaki gücünü arttırmaya yönelik düzenlemeler ile rekabet gücü artış göstermiştir. Bununla birlikte, uluslararası taşımada öne çıkan belge temininde yaşanan güçlükler, liman hizmetlerindeki gecikmeler, depo ve yurt içi taşıma bedelleri gibi doğrudan masraflar ve liman, gümrük hizmetlerindeki zaman kayıpları sebebiyle oluşan dolaylı masraflar sektöre olumsuz yönde etki etmektedir. Türkiye'nin 2023 hedeflerini gerçekleştirebilmesi için, yukarıda bahsi geçen tüm olumsuzlukları işbirliği ile en asgari düzeye indirmesi, mevzuatın altyapısını iyi kurması ve verilen hizmetin müşteriler tarafından kabul edilebilir bir fiyatta ama kaliteli sunuluyor olması gereklidir(TÜSiAD, 2012:18).

Türkiye'nin Ulaşım 2023 hedefleri aşağıdaki gibi özetlenebilir: (B.K.K.A, 2013: 24).

\section{Karayolu için 2023 hedefleri:}

$32.000 \mathrm{~km}$ toplam bölünmüş yol uzunluğu,7.500 km toplam otoyol uzunluğu, $67.000 \mathrm{~km}$ toplam karayolu uzunluğu, Karayolu ağının tamamının Bitumlu Sıcak Karışı (BSK) asfalta dönüştürülmesi, Halen 3,97 olan 100 milyon taşıt $\times \mathrm{km}$ başına düşen olun oranının 1,00'ın altına düşürülmesi.

Demiryolu ulaşımı için 2023 hedefleri:30.000 km toplam demiryolu uzunluğu, 11.000 km hızlı tren işletmeciliği yapılan demiryolu (yukarıdaki toplama dahil), 8.000 yük vagonu,Raylı taşıt sanayinin geliştirilmesi, Başta Hicaz Demir yolu olmak üzere, Kavkaz-Samsun-Basra, Kars-Tiflis-Bakü, Güneydoğu Asya, İstanbul-Basra, Kuzey Demiryolu Koridoru, gibi ülkemizi demiryolu ile bölge ülkelerine bağlayacak yeni koridor ve bağlantıların oluşumuna yönelik bölgesel projelerin gerçekleştirilmesi.

Havayolu ulaşımı için 2023 hedefleri:350 milyon/yıl yolcu kapasiteli havaalanı ağı, 750 uçaklık (en az 100 geniş gövde, 450 dar gövde, 200 bölgesel uçak) Türk Sivil Hava taşımacılık filosu, 5.000 uçağa bakım verebilecek en az 2 adet uçak bakım ve eğitim merkezi niteliğinde havaalanı, uluslararası tanınırlığı olan bir uçak fabrikası.

Denizcilik sektörü için 2023 hedefleri: Limanlarımızda 850 milyon ton yük elleçlenmesi, limanlarımızda 32 milyon TEU konteyner elleçlenmesi, Türk ticaret yüklerinin en az \%50'sinin Türk sahipli gemilerle taşınması, Türk tersanelerinin global siparişte ilk 5 içinde yer almaları.

\subsection{Lojistik Köyler}

Lojistik köye dair standart bir tanım olmadığından, farklı birçok tanım mevcuttur. Bunlardan bazıları;

Lojistik köy; kısa ve uzun mesafeli ulaştırma hizmet modlarının (hava, demir, deniz ve içsu) ortaklaşa yapıldığı yeri ifade etmektedir. Lojistik köylerde ulaştırmanın yanı sıra, katma değerli hizmetlerde verilmektedir(Laitio ve Perala: 2004, 6).

Lojistik köyler; gerekli kamu hizmetlerine ve altyapıya sahip, büyüklükleri ise bulundukları bölgenin konumuna, nüfusuna, sanayi ve ticaretinin yapısına göre değişen yerlerdir(Bamyacı, 2008:6). 
Lojistik köy kavramı, ülkemizde terminoloji boşluğu bulunması sebebiyle farklı isimlerle de ifade edilmektedir; yük köyü, lojistik alan, lojistik merkez, lojistik odak, lojistik park, lojistik üs, dağıtım parkı(Tanyaş, 2010). Fakat çoğunlukla lojistik köy kavramı bölgesel, sınırlı alan için kullanılmakta iken Türkiye'nin tamamı için ise lojistik üs kavramı kullanılmaktadır. Ulaştırma, Denizcilik ve Haberleşme Bakanlığı ilk önce "lojistik köy" kavramını kullanmış sonradan ise "lojistik merkez" kavramını kullanmayı tercih etmiştir. Yapılan bu çalışmada "lojistik köy" kavramı tercih edilmiştir.

Lojistik köy kavramı ilk olarak ABD’de endüstrinin gelişmesiyle doğmuştur. Bu kavramın Japonya'da da trafik sıkışıklığını, çevresel, enerji ve işgücü maliyetlerini azaltmak için önerildiği de bilinmektedir. Daha sonra Batı Avrupa'ya geçmiş olan uygulamanın ilk örnekleri Fransa'da geniş ölçekte Paris bölgesel alanında Garanor ve Sogoris (Rungis)'te oluşturulmuştur. 1960'ların sonları ve 70'lerin başında ise lojistik köyler, i̇talya ve Almanya'da görülmeye başlanmıştır. Bu sırada lojistik köy kavramı da şekillenmeye başlamış ve karayolu/demiryolu gibi çok türlü taşımacılığını sağlar hale gelmiştir(Görgülü, 2012: 6).

Lojistik köylerde verilen hizmetler; uzun mesafe taşımacılık, dağıtım, malların sınıflandırma ve gruplandırılması, depolama, ayrıştırma ve bütün bu işlemlerin yapılabilmesi için gerekli olan bankacılık, sigortacılık gibi diğer katma değer oluşturan hizmetler olarak özetlenebilir(Aydın ve Öğüt, 2008:3).

Küreselleşmenin ortaya koyduğu güncel yaklaşımlardan biri olan lojistik köyler, lojistiğe dair tüm faaliyetleri bir araya getirerek maliyet, hız, etkinlik, iyileştirme ve sürdürülebilirlik açısından çevresel fayda sağlayan önemli bir rekabet avantajı oluşturmaktadır(Gün, 2012: 384-389).

Lojistik köy, ulusal ve uluslararası tüm lojistik ve lojistikle ilişkili faaliyetlerin, kamu ve özel sektöre ait çeşitli işletmeler tarafından yerine getirildiği tanımlanmış bölgelerdir. Genel olarak lojistik köyler, büyük ve önemli üretim merkezlerine (sanayi bölgeleri, iş merkezleri vs.), şehirlere, demiryolu, karayolu hatlarına ve mümkünse limanlara yakın, ancak şehir trafiğini doğrudan etkilemeyecek noktalarda kurulmaktadır. Lojistik köylerin ana taşıma koridorlarıyla etkin bağlantıları mevcut olup limanların yakınında kurulan intermodal terminallerdir. Çok geniş imkânlara sahip bu alanlarda, yüklerin iskele ve depo arasında konteynerlama ve boşaltma işlemleri kara veya demiryoluyla oldukça hızlı yapılarak gerçekleştirilmektedir. Lojistik köylerde bulunan demiryolu ile bağlantılı depolar, dolu boş konteyner depolama alanları ve elleçleme sahaları sayesinde elleçleme süre ve maliyetleri düşmekte, karayolu ile yapılan taşımacılık azalmaktadır(Demiroğlu ve Eleren, 2014: 190)

Lojistik faaliyetler ülke ekonomileri içerisinde, hem iş dünyası ve toplumsal açıdan yarattıkları katma değerle, hem de sektörel olarak gayri safi milli hasıla içerisindeki payları ile önemli bir konumdadır. Lojistik köylerde faaliyet gösteren işletmelerin etkili lojistik yönetimi sayesinde, müşterilere ürün ve hizmetin zaman ve yer faydası ile etkin bir şekilde sunulabilmesi için çalışan pazarlama çalışmalarının başarısı yükselmektedir(Kayabaşı, 2010: 86).

Lojistik köyler, en az 250 hektar alan üzerine kurulmuş ve intermodal taşımacılığa tüm taşıma yöntemleriyle entegre olmalıdır. Merkez binası depoları, antrepoları, sosyal alanları, katma değerli hizmetlerin verildiği bölümleri, gerekli araç gereci olması gerekmektedir.

Lojistik köy konsepti, çeşitli taşımacılık ve lojistik şirketlerinin hizmet sunduğu genel alanlardır. İşletmeler, kendi altyapılarını kendi imkanlarıyla kurmak istediklerinde harcayacakları kaynaktan, daha az bir maliyetle bu alanlarda faaliyetlerini yürütebilirler, bunun aksini yapan işletmelerin, bilhassa üçüncü parti işletmelerle çalışmayı reddedenlerin olumlu geri dönüşler almaları da zorlaşır. Dolayısıyla, lojistik köyler, işletmelerin faaliyetlerini tek başlarına yürütebilecekleri basit bir alt yapı değil, kapsamlı ve zengin imkanlar sunan ticari bir girişimdir(Tsamboulas ve Dimitroppulos, 1999:142).

Lojistik köyler gerek teknoloji gerekse fiziksel ve hizmet altyapıları gerektiren maliyetli oluşumlardır, bu nedenle kamu özel sektör ortaklıklarına dayanarak oluşturulurlar(Shahryar veMoayedfar, 2008:167).

\section{Dünya'da Lojistik Köyler}

Dünya üzerindeki lojistik köy uygulamalarının Avrupa'da özellikle, Batı Avrupa'da yoğunlaştığı görülmektedir. Sayı olarak en fazla lojistik köyü Almanya'da bulunmaktadır. Geçtiğimiz son 20 yılda Almanya'da, toplam 33 
lojistik köy kurulmuştur. Bu lojistik köyler içinde olan Bremen Lojistik Köyü en faal olanlarındandır, yılda 90 bin TEU malın elleçlemesi gerçekleştirilmektedir.

Avrupa'da yer alan diğer lojistik merkezlere göz attığımızda; İtalya, İspanya, Danimarka, Fransa, Macaristan, Portekiz, Yunanistan, Ukrayna ve Lüksemburg'da 60'ın üzerinde lojistik köy tanımına giren yapılanmanın olduğu görülmektedir(Baran vd., 2008:2-3). Yaklaşık 2 bin ile 3 bin arası işletmeci bu lojistik merkezlerden yararlanmaktadır.

Almanya'da 33 lojistik köy, bunlarda da toplam 1200 işletme ve 40.000 istihdam bulunmaktadır. Almanya'da Bremen Lojistik Köyü'nden başka Leipzig Lojistik Köyü (8330 hektar), Lubeck Lojistik Köyü (264 hektar) en gelişmiş lojistik köylerdir. Fransa'da ise 23 adet lojistik köy bulunmaktadır ve bunların en başında Rungis(Sogaris) Lojistik Köyü gelmektedir. ${ }^{7}$ italya'da ise lojistik hub ${ }^{8}$ olan lojistik köyler daha çok Milan etrafında oluşturulmuştur. Özellikle Bologna lojistik köyü (200 hektar) en gelişmiş lojistik köyüdür. ${ }^{9}$ isspanya ise coğrafi konumu olarak Avrupa'nın lojistik anahtarı rolündedir ve çok iyi organize edilmiş bir karayolu ağ ile çevrelenmektedir. En gelişmiş lojistik köyü Barselona Lojistik Köyü'dür(Gilberto, 2006). 2012 yılı itibariyle Ayrupa'da toplam 70 adet lojistik köy bulunmaktadır.

Çalışmada Avrupa'daki lojistik köylerden, dünyaca önemli kabul edilmiş ve lojistik pazarını etkileyen iki büyük lojistik köy üzerinde durulacaktır; Bologna- İtalya, Plaza - İspanya.

Lojistik köy tanımı 1992 yılında Europlatforms tarafından çıkarılmış, ulaşım ve iletişim şebekelerinde $A B$ inisiyatifleri doğrultusunda bir Avrupa şebekesi yaratılmasına karar vermek ve iyileştirmek amacıyla ortak çatı altında hareket etmeyi sağlamıştır. Europlatforms temel amacı lojistik köylerinin ve intermodal terminallerin ulaşım ve lojistik faaliyetlerinin gelişimi bakımından stratejik önemini desteklemek olan ve Avrupa çapında 9 ülkeyi temsilen 55 üyesi (55 lojistik köy) bulunan Avrupa Lojistik Köyleri Birliği'dir(izTO, 2008: 3).

\section{Bolonya Lojistik Köyü - İtalya (Interporto Di Bologna)}

İtalya'da ülke geneline yayılmış 21 lojistik merkez UIR (Unione Interporti Riuniti) adı altında bir birlik altında toplanmışlardır. Bu birlik kar amacı gütmeyip, lojistik merkezler ile karayolu, denizyolu ve havayolu taşımacılığı yapan kurum ve kuruluşlarla sürekli ve sağlam bir ilişkinin geliştirilmesini amaçlamaktadır. Bu yolla intermodal taşımacılığın daha da geliştirilmesi hedeflenmektedir. İtalya'daki 21 lojistik merkezden biri olan Bologna lojistik köyü entegre bir kara, demiryolu ve lojistik sistem altyapısına sahiptir. Merkez doğrudan ulusal demiryolu ve otoyol sistemine bağlıdır(Tanyaş ve Hazır, 2011: 242-243).

Bolonya Lojistik Köyü 1971 yılında taşımacılığın karayolundan ziyade demiryoluna kaydırılması, lojistik firmalarına avantajlar sağlayarak daha rekabetçi hale gelmeleri, çoklu taşımacılık modlarının kullanımının sağlanması amacıyla kurulmuştur. Kamu ve özel sektör girişimidir. İşletici şirket, Interporto Bologna SpA'dır. Kurucu ortakları içerisinde ağırlıklı olarak belediye, vilayet ve ticaret odası yer almaktadır. Sermayesi 13.743.928 Avro'dur. Bolonya lojistik Köyü'nde haftada ortalama olarak 139 tren giriş çıkışı olmaktadır. Kamyon giriş çıkışları ise günde 4500 civarındadır. ${ }^{10}$

2007 yılı içinde karayolu ile taşınan yük 2,6 milyon ton, demiryolu ile taşınan yük ise 2,2 milyon ton kadardır. Senede 250.000 TEU konteynır elleçlenmektedir. Köy, 5 ana tren yolu ve 4 ana karayolu üzerinde bulunmaktadır ve Bologna şehrinin merkezinden $12 \mathrm{~km}$ uzaktadır. A13 Bologna-Padua kara yoluna direkt bağlantısı bulunmaktadır. 2.000.000 m2'lik alanın $650.000 \mathrm{~m} 2$ 'si tamamen demir yolu taşımacılığına ayrılmış durumdadır. Lojistik köyde verilen hizmetler, şu şekilde sıralanabilir: intermodal hizmetler, genel depolar, gümrüklü depolar, doldurma istasyonları, yükleme/boşaltma için park alanı, gümrük alanı, postane, otobüs hizmeti, restoran, banka, araç yıkama hizmetleri. ${ }^{11} 2007$ yılında toplam yük trafiği, 4.825 .000 tondur.

\footnotetext{
${ }^{7}$ Industrial Logistics Propertyin the future, A pan-European Perspective, 2005.

${ }^{8}$ Hub, taşımacılıkta yolcuların ve kargoların (yük) taşıtlar ya da değişik taşımacılık uygulamaları (deniz, kara, hava, tren gibi) arasında geçiş yaptığı yerlere verilen isimdir.

${ }^{9}$ http://www.promobologna.it/binary/promo bologna/brochure/22 2 NEW INTE RPORTO.1208247963.pdf.

10 http://www.izto.org.tr/portals/0/lojistik merkez kavrami ve italyadaki lojistik merkezler.pdf.

${ }^{11}$ http://www. promobologna.it/binary/promo bologna/brochure/22 2 NEW INTERPORTO.1208247963.pdf.
} 
Bolonya Lojistik Köyü'nün ulaşım bağlantıları, teknik verileri ve köyde verilen hizmetler; ${ }^{12}$

Bağlantılar: Karayolu Ulaşımı: A13 Karayolu Erişimi (Bolonya-Padova, Bolonya Liman çıkışı), Demiryolu Ulaşımı: Bolonya-Ferrara hattı.

Teknik veriler: Toplam alan: $2.000 .000 \mathrm{~m}^{2}$, genişleme alanı: $2.700 .000 \mathrm{~m}^{2}$, konteyner terminali: $147.000 \mathrm{~m}^{2}$, demiryolu terminali: $277.000 \mathrm{~m}^{2}$, intermodal terminali: $13.000 \mathrm{~m}^{2}$, kamusal antrepolar: $150.900 \mathrm{~m}^{2}-51.500 \mathrm{~m}^{2}$ kapalı alan, demiryoluyla kesişen antrepolar: $66.800 \mathrm{~m}^{2}-25.400 \mathrm{~m}^{2}$ kapalı alan, alandaki taşıma ve lojistik firma sayısı: 81 uluslararası sevkiyat firması, intermodal taşıma operatörü, temizlik firmaları, çekiciler, ulusal taşıyıcı firmalar, taşıma ve dağıtım firmaları, hava yükü taşıma firmaları.

Hizmetler: Ulusal ve enternasyonal demiryolu bağlantıları: Sicilya, Sardenya, Apulya ve Cenevre limanları, La Spezia, Legorn, Giaia Tauro, Taranto. Luebeck, Helsinki, Hoeje-Taastrup, Helsingborg, Kopenhag, Metz-Sablon ve Güney İtalya'yla direkt demiryolu bağlantısı. Taşıma ve lojistik hizmetler: antrepolar, temiz \& temiz olmayan mallar için depo alanları, vagonlardan antrepolara direkt aktarılan malların idaresi, tam lojistik hizmet, depolama yerleri, intermodal yükleme birimi nakliyesi, konteyner denetleme birimleri, hasar tahmini ve tamiratı, mal dağıtım idaresi, demiryolu hizmetleri. Gümrük Hizmetleri: Mevcut. Kamu hizmetleri: postane, telefon kulübeleri, şehir merkezine ve şehir merkezinden alana otobüs ulaşımı. Özel hizmetler: Banka, Bolonya Ticaret Odası Ofisi, bar, restoran, araba ve kamyon yıkama istasyonları. Bilgi -işlem teknolojileri: projedekileri de kapsayan tüm yapılar telematik, optik sistem kablolarıyla donatılmıştır. Bu ağ bağlantısı, lojistik köyde yer alan firmaların kolayca veri aktarımı yapmasını, e-posta hizmetlerinden yararlanmasını, yerel otoriteler tarafından sağlanan veri tabanı ve bilgi sistemine erişmesini sağlar, (Iperbole-Bolonya ve Emilia-Romanya bölgesi için internet hizmeti), alanı terk eden kamyonları Interpass sistemiyle kontrol etmek, güvenlik ve alarm sistemini merkezileştirmek. Alanda çalışan tahmini kişi sayısı: 1.500. Araç park alanı (toplam alan $\mathrm{m}^{2}$ ): $16.000 \mathrm{~m}^{2}$ ışıklandırılmış, güvenlikli ve etrafı çitle çevrilmiş, ücretli, kamyon park alanı $382,538 \mathrm{~m}^{2}$, ağır vasıta ve otomobiller için ücretsiz park alanı.

\section{Plaza Lojistik Köyü - İspanya}

Lojistik maliyetleri düşürmek amacıyla İspanya'da 21 lojistik köy kurulmuştur. İspanya'daki lojistik köyler incelendiğinde, bunlardan 12 tanesinin denize çok yakın yada kıyı bölgelerde konuşlanmış oldukları görülmektedir. Geriye kalan 9 lojistik köy iç bölgelerde yerleşik durumdadır. İspanya'daki lojistik köyler 1991 yılında, İspanya Lojistik Merkezler Birliği (ACTE- Asociación de Centros de Transporte de España) çatısı altında bir birlik oluşturmuşlardır. ACTE bir komite tarafından yönetilmekte ve komitenin başkanlığını Ulaştırma Genel Müdürü yapmaktadır. ACTE birlik içerisindeki lojistik köyler arasında tecrübe ve bilgi alışverişine ortam sağlamakla kalmamakta ayrıca lojistik köyler içerisindeki işletmelerin daha iyi bir şekilde gelişmelerine imkan sağlamaktadır(Tanyaş ve Hazır, 2011: 245-246).

Plaza Lojistik Köyü’nün teknik verileri ve köyde verilen hizmetler(izTO, 2008: 46);

Teknik Veriler: Toplam alan: $12.826 .898 \mathrm{~m} 2$, genişleme alanı: $563.630,00 \mathrm{~m}^{2}$, iş alanları: $181.333,00 \mathrm{~m}^{2}$, özel donanımlı alanlar: $840.834,00 \mathrm{~m} 2$, aktivite alanları: $5.015 .518,00 \mathrm{~m}^{2}$, ticari alan: $442.402,00 \mathrm{~m}^{2}$, hizmet alanı: $101.891,00 \mathrm{~m}^{2}$, kamusal yeşil alanlar: $2.192 .987,00 \mathrm{~m}^{2}$, entegre iş merkezi: $88.235,00 \mathrm{~m}^{2}$, özel kullanıma ayrılmış alan: $1.736 .072,00 \mathrm{~m}^{2}$, demiryolu İle bütünleşik aktarma alanı: $106.772,00 \mathrm{~m}^{2}$, intermodal havaalanı Lojistik Bölge: $131.803,00 \mathrm{~m}^{2}$, endüstriyel lojistik bölge: $3.233 .828,00 \mathrm{~m}^{2}$, intermodal demiryolu -lojistik bölge: $665.753,00 \mathrm{~m}^{2}$, demiryolu sistemi: $2.029 .083,00 \mathrm{~m}^{2}$, alanda taşıma ve lojistik firma sayısı: 140 , altyapı: $342.002,00 \mathrm{~m}^{2}$.

Verilen Hizmetler: Kamusal Hizmetler: Yağmur suyu için drenaj sistemi, su tesisatı, içme suyu, endüstriyel su, gaz, elektrik (min. Voltaj), telekomünikasyon sistemi. Özel Hizmetler: Restoran, kafe - bar, yemek servisi, banka. Bilgi - İşlem Teknolojiler: Gelişmiş telekomünikasyon ağı: 763,000 lineer metre. Araç park alanı: 170.273,00 m². Yol şebekesi ve araç park alanı: 1.736.072,00 $\mathrm{m}^{2}$.

\footnotetext{
12 http://www.izto.org.tr/portals/0/lojistik merkez kavrami ve italyadaki lojistik merkezler.pdf.
} 


\section{Türkiye'de Lojistik Köyler}

655 sayılı Kanun Hükmünde Kararname ile "Lojistik köy, merkez veya üslerin yer, kapasite ve benzeri niteliklerini belirleyerek planlamak, kurulmalarına ilişkin usul ve esasları belirlemek ve izin vermek, gerekli arazi tahsisi ile altyapıların kurulması hususunda ilgili kuruluşları koordine etmek ve uygulamasını takip etmek ve denetlemek" görevi Ulaştırma, Denizcilik ve Haberleşme Bakanlığı tarafından, Demiryolu Düzenleme Genel Müdürlüğü’ne verilmiştir(TCDD).

Lojistik sektörümüz hızla gelişmektedir. Lojistik Merkezler Kurulması Projesi ile etkin karayolu ulaşımı olan ve müşteriler tarafından tercih edilebilir kent merkezlerinin dışındaki alanlarda, ihtiyaçlara cevap verebilecek özellikte alanlar oluşturulması, teknolojik ve ekonomik gelişmelere uygun olarak, özellikle organize sanayi bölgelerine yakın ve yük potansiyeli yüksek olan bölgelerin yeniden yapılandırılmaları amaçlanmıştır. Lojistik merkezlerin, öncelikle organize sanayi bölgeleriyle bağlantılı olarak yük taşıma potansiyelinin yoğun olduğu yerlerde kurulması planlanmıştır. ${ }^{13}$

Türkiye'de lojistik köy projesileri;

- $\quad$ TCDD (19 adet lojistik köy projesi)

- Altyapı Yatırımları Genel Müdürlüğü (1 adet lojistik köy projesi)

- İstanbul Büyükşehir Belediyesi ( 2 adet lojistik köy projesi; Hadımköy Lojistik Köyü ve Tuzla Lojistik Köyü)

- $\quad$ Kamu ve özel sektör ortak girişimi ( 2 adet lojistik köy projesi; Tekirdağ-Çorlu Lojistik Köyü ve Manisa Lojistik Köyü)

Yukarıdaki projeler, ülkemizde lojistik köy üzerine yapılmış çalışmaların toplamıdır. Fakat çalışmamızda TCDD'nın ve AYGM'nün bağlı olduğu Ulaştırma, Denizcilik ve Haberleşme Bakanlığı'nın yapmış olduğu lojistik köy projelerinin üzerinde durulacaktır.

Ülkemizde 2005 yılında ilk lojistik köy projesi başlatılmış ve 2015'e gelindiğinde ise bu projeler toplamda 20'ye ulaşmıştır. 19 proje Türkiye Cumhuriyeti Devlet Demiryolları(TCDD)'na aittir diğer 1 proje ise (İzmir-Kemalpaşa Lojistik Köyü) Altyapı Yatırımları Genel Müdürlüğü’ne aittir.

2005 yılında başlatılan lojistik merkezler kurma çalışmaları; Altyapı Yatırımları Genel Müdürlüğü (AYGM), Türkiye Odalar ve Borsalar Birliği (TOBB), Türkiye Ekonomi Politikaları Araştırma Vakfı (TEPAV), Gümrük ve Turizm İşletmeleri A.Ş. (GTi), UND Lojistik Yatırım A.Ş., Demiryolu Taşımacılığı Derneği (DTD), Uluslararası Taşımacılık ve Lojistik Hizmet Üretenleri Derneği (UTi- KAD) vb. gibi kurum, kuruluş ve derneklerle koordineli olarak yürütülmüştür. Lojistik merkezler hizmete girdiğinde; lojistik sektörüne yıllık 40 milyar dolarlık katkı, 27 milyon ton ilave taşıma imkanı ile 9 milyon metrekare konteyner stok ve elleçleme sahası kazandıracak. Türkiye'nin tüm bölgelerine yayılan lojistik merkezler ayrıca, 10 bin kişilik ek istihdam sağlayacaktır. ${ }^{14} 2005^{\prime}$ ten 2014'e kadar lojistik köyler için oluşturulan plan dahilindeki 550 milyon TL'lik projeye şimdiye kadar 191 milyon TL harcandı, 2014 'te ise 70 milyon TL harcanmıştır(Uysal, 2014).

TCDD, 4-5 yıldır özelleştirmeye gitmeyi planlamaktadır. \%49 özel sektör, \% 51 devlet pay sahibi olacaktır. Böylece TCDD hem taşıyan hem taşıtıcı olacaktır. Her lojistik köyün bir pazarlama sorumlusu olacak ve bazı fiyatlarda opsiyon sağlanacaktır. Böylelikle özel sektör işin içine girecek yatırım artacak, rekabet başlayacaktır. 2023 Hedefleri doğrultusunda demiryollarının 3'te 2'si tadilat halindedir. Yine bu hedefler doğrultusunda $12.500 \mathrm{~km}$ olan toplam demiryolumuz 25.000km'ye çıkarılması planlanmaktadır. Ayrıca, 4.koridor(Pan Avrupa Ulaştırma Ağı - Berlin-Dresden-Nurnberg (Almanya), Prag-Brno (Çekoslavakya), Viyana (Demiryolu)(Avusturya), Bratislava-(Slovakya), Gyor-Budapeşte- (Macaristan) Arad-Craiova-Bucharest-Köstence(Romanya), SofyaPlovdiv (Bulgaristan) Selanik (Yunanistan), Istanbul (Türkiye) (Kara ve demiryolu, Tuna ferry bağlantısı, hava ve deniz limanları, kombine taşıma, toplam uzunluk 3.258 km.) üzerinden Kapıkule-Gürcistan-Çin demiryolu hattı oluşturulmak istenmektedir. Avrupa'dan Çin'e 40 günde denizyolu ile varılırken, bu sayede demiryolu ile 10 günde varılacaktır. Saatte 1 tren çalışacak ortalama bir seferde 2.500 ton mal taşınacaktır. Bu proje ile Traceca

\footnotetext{
13 http://www.udhb.gov.tr/images/faaliyet/c19d85352980eaf.pdf

14 http://www.denizticaretgazetesi.org/turkiyenin lojistik koyleri haber8059.html
} 
devre dışı kalacak, başrole Türkiye geçecektir ve Türkiye dünyada küresel üs olma yolunda hızla ilerleyecektir. Projenin Türkiye'den geçeceği noktalar;

\section{Şekil 1: 4.Koridor-Çin Demiryolu Hattı Projesi'nin Türkiye Uzantısı}

\section{Köprü}

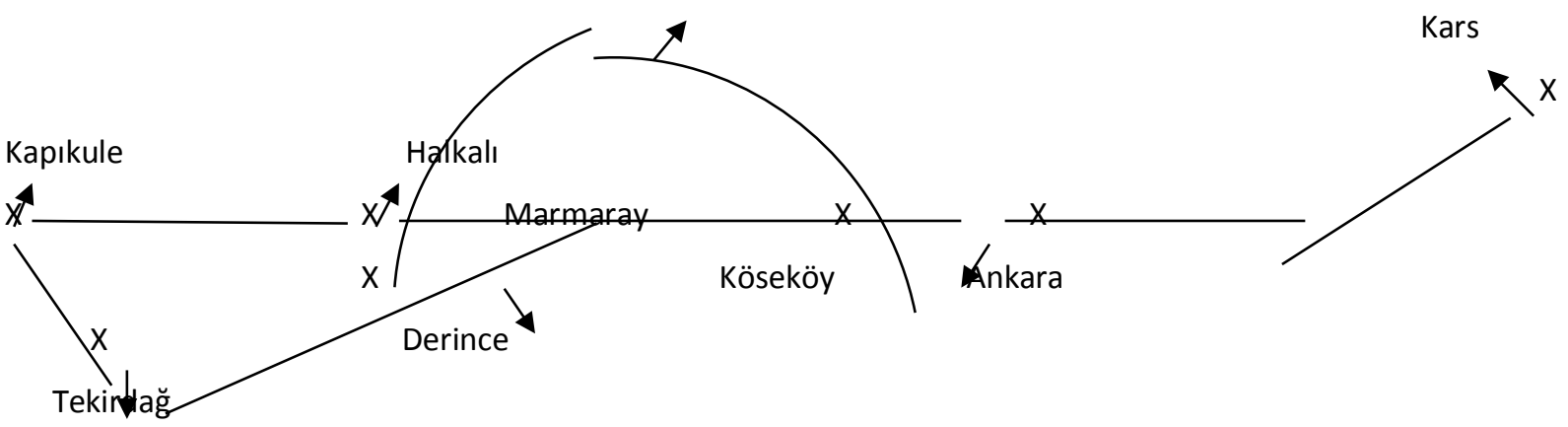

Türkiye, 2023 vizyonu kapsamında ihracat hedefini 500 milyar dolara yükseltmeyi ve Asya, Avrupa, Afrika'da lojistik güç haline gelmeyi amaçlamaktadır. Lojistik merkezlerin, öncelikle organize sanayi bölgeleriyle bağlantılı olarak yük taşıma potansiyelinin yoğun olduğu; İstanbul (Halkalı): 220.000m², Kocaeli (Köseköy): 694.000 m², Eskişehir (Hasanbey): $541.000 \mathrm{~m}^{2}$, Balıkesir (Gökköy): $211.000 \mathrm{~m}^{2}$, Kayseri (Boğazköprü): $620.000 \mathrm{~m}^{2}$, Samsun (Gelemen): $258.000 \mathrm{~m}^{2}$, Denizli (Kaklık): $125.000 \mathrm{~m}^{2}$, Mersin (Yenice): $416.000 \mathrm{~m}^{2}$, Erzurum (Palandöken): $350.000 \mathrm{~m}^{2}$, Uşak: $140.000 \mathrm{~m}^{2}$, Konya (Kayacık): $1.000 .000 \mathrm{~m}^{2}$, İstanbul (Yeşilbayır): $1.000 .000 \mathrm{~m}^{2}$, Bilecik (Bozüyük): $654.000 \mathrm{~m}^{2}$, Kahramanmaraş (Türkoğlu): $805.000 \mathrm{~m}^{2}$, Mardin (GAP): $441.000 \mathrm{~m}^{2}$, Sivas: $500.000 \mathrm{~m}^{2}$, Kars: $300.000 \mathrm{~m}^{2}$, İzmir (Kemalpaşa): $3.000 .000 \mathrm{~m}^{2}$ (AYGM), Şırnak (Habur): Toprakkale-Kilis-ÇobanbeyNusaybin-Cizre-Silopi-Habur Demiryolu Projesi kapsamında değerlendirilecektir. Bitlis (Tatvan): 660.000 $\mathrm{m}^{2}$ olmak üzere toplam 20 yerde inşa edilmesi planlanmıştır(TCDD).

Bu 20 köy içerisindeki alan olarak en büyük lojistik köy yapım aşamasında olan, İzmir (Kemalpaşa) Lojistik Köyü, en küçük lojistik köy ise Denizli (Kalkık) Lojistik Köyü'dür.

İşletmeye Açılan Lojistik Köyler: Samsun(Gelemen), Uşak, İstanbul(Halkalı), Eskişehir(Hasanbey), Denizli(Kalkık), İzmit(Köseköy), Balıkesir(Gökköy). Yapımı Devam Eden Lojistik Köyler: Bilecik(Bozüyük), Mardin, Erzurum(Palandöken), Mersin(Yenice), Kahramanmaraş(Türkoğlu), İzmir(Kemalpaşa) 


\section{Harita 1: Türkiye'deki Lojistik Köyler}

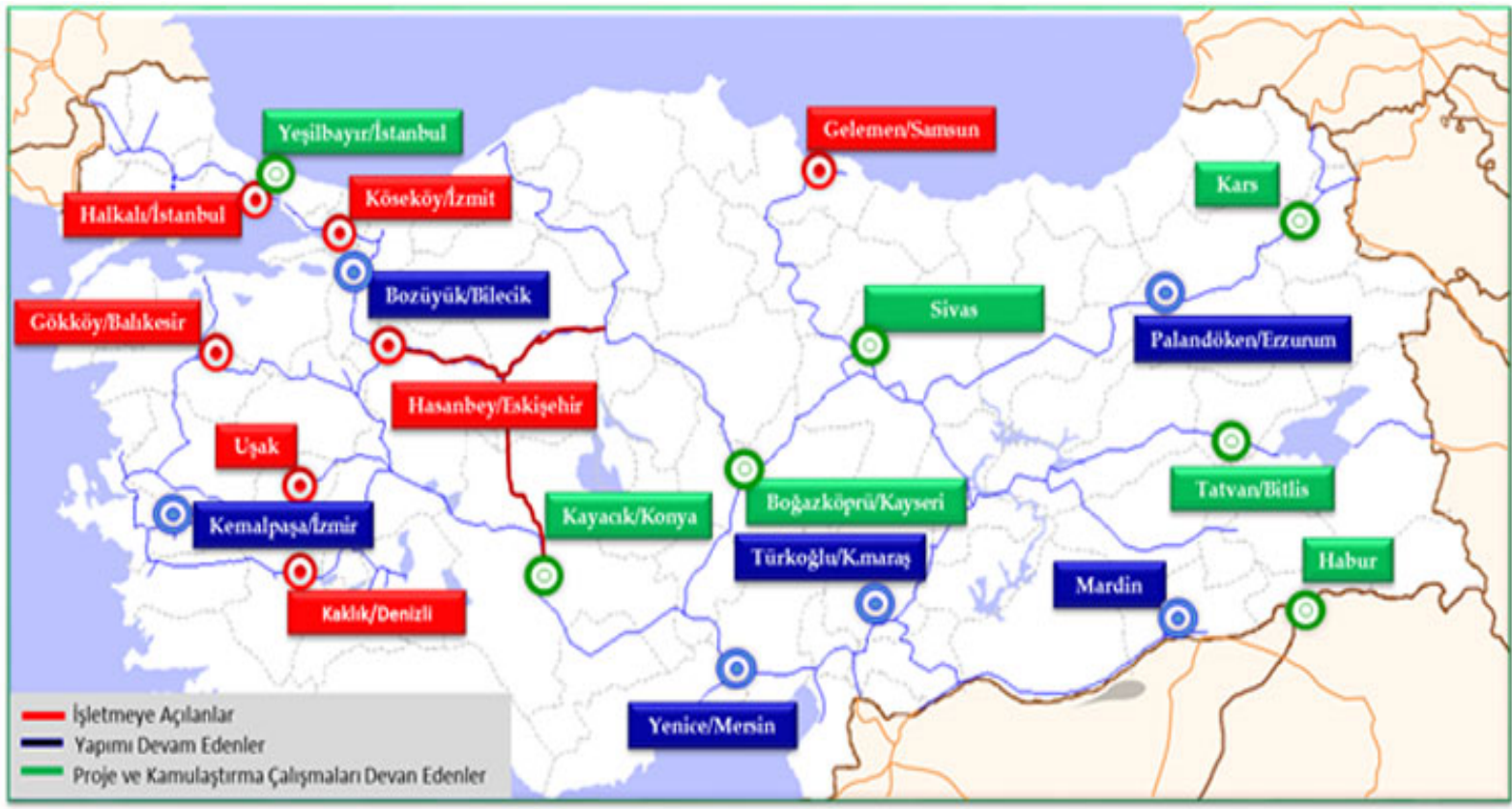

Kaynak: Lojistik Merkezler, http://www.tcdd.gov.tr/lojistik-merkezler+m129 (Erişim Tarihi:08.04.2016)

Tablo 2: TCDD Lojistik Köylerin Mevcut Yük Potansiyelleri

\begin{tabular}{|l|c|}
\hline Lojistik Köyler & $\begin{array}{c}\text { Mevcut Yük Potansiyeli } \\
\text { (ton/yıl) }\end{array}$ \\
\hline İstanbul (Halkalı) & 944.000 \\
\hline Kocaeli (Köseköy) & 600.000 \\
\hline Eskişehir (Hasanbey) & 215.000 \\
\hline Samsun (Gelemen) & 500.000 \\
\hline Denizli ( Kalkık) & 634.000 \\
\hline Balıkesir (Gökköy) & 390.000 \\
\hline Uşak & 113.000 \\
\hline
\end{tabular}

Kaynak: Türkiye'deki Lojistik Köyler ve Önemi

http://www.lojistikhatti.com/haber/2012/12/turkiyedeki-lojistik-koyler-ve-onemi (Erişim Tarihi: 11.04.2016)

İşletmeye açılmış olan 7 lojistik köyün içlerindeki toplan alan bakımından en geniş Halkalı Lojistik Köyü, en dar ise Uşak Lojistik Köyü'dür. Mevcut yük potansiyelleri de yine aynı doğrultudadır.

\section{Gelemen- Samsun Lojistik Köyü}

Faaliyete geçmiş 7 lojistik köyden biridir. Türkiye'nin ilk lojistik köyü Gelemen'de (Samsun) inşa edilerek 1. etabı 06.07.2007 tarihinde işletmeye açılmıştır. Samsun Türkiye'nin ve Karadeniz'in en önemli liman kentlerinden 
biridir. Ayrıca Karadeniz kıyılarıyla iç kesimleri birbirine bağlayan sadece iki demiryolu hattı bulunmakta olup, bunlardan birinin son istasyonu Samsun'dur. Ayrıca gerek il merkezi, gerekse Bafra ve Çarşamba ilçeleriyle dikkate değer bir sanayi üretimine sahiptir. Bu durum Samsun'u ulusal ve uluslararası alanda önemli bir ulaşım ve ticaret merkezi haline getirmektedir. Dolayısıyla burada yüksek kapasiteli bir lojistik köyün kurulması doğru ve yerinde bir tercihtir. Lojistik köy üzerinden ağırıklı olarak demir, hurda, rulo sac, bakır, klinker, konteyner, çimento, kömür, kereste, buğday, gıda maddesi, un ve gübre gibi ürünlerin taşınması ve dağıtımı gerçekleştirilecektir(Karadeniz ve Akpınar, 2011:56).

Samsun Valisi Hüseyin Aksoy'un Samsun'daki lojistik köy hakkında verdiği bilgiler; Samsun lojistik köyü 672 dönümlük alana sahiptir. Samsun Lojistik Köyü, Tekkeköy ilçesi yakınında kurulmuştur. Samsunport Limanı’na (ana giriş) 20 km, Çarşamba Havaalanı'na ise 10 km uzaklıktadır. Samsun - Ordu karayolu, Lojistik Köy'ün 1.8 km kuzeyinden geçmektedir. Samsun-Ordu Karayolu doğu-batı yönünde ana bağlantı yolu olup, aynı zamanda Samsun'u Ankara'ya bağlayan anayoldur. Samsun - Çarşamba demiryolu hattı Lojistik Köy'ün tam olarak yanından geçmektedir. Samsun Lojistik Köy projesi yürütme kurulunu oluşturan kurumlarda Samsun Ticaret ve Sanayi Odası'nın yüzde 25, il Özel İdaresi ve Büyükşehir Belediyesi'nin yüzde 20, Samsun Ticaret Borsası'nın yüzde 15, Tekkeköy Belediyesi ve Samsun Merkez Organize Sanayi Bölgesi'nin yüzde 15 ve Orta Karadeniz Kalkınma Ajansı'nın da doğal üye olarak hisseleri bulunmaktadır. ${ }^{15}$

\section{Gökköy- Balıkesir Lojistik Köyü}

Gökköy Lojistik Köyü, 15 Mart 2015’te hizmete başlamıştır. Gökköy Lojistik Köyü hakkındaki genel bilgiler; ${ }^{16}$

- $\quad 8.247 \mathrm{~m}^{2}$ kapalı hizmet binası ile $59.560 \mathrm{~m}^{2}$ beton saha, rampa ve yükleme alanı mevcut bulunan Balıkesir (Gökköy) Lojistik Merkezi'nde Türkiye lojistik sektörüne 1 milyon ton taşıma kapasitesi sağlanacak, ülkemize 211 bin $\mathrm{m}^{2}$ lojistik alan kazandırılacak.

- Büyük Anadolu Lojistik Organizasyonları(BALO) projesi’nin, en önemli güzergahı Balıkesir'dir.

BALO nedir? 2011 yılında Türkiye'nin çatı sivil toplum örgütü olan TOBB Türkiye Odalar ve Borsalar Birliği'nin öncülüğü ve katılımında, Türkiye'nin birçok yöresinden, oda, borsa ve organize sanayi bölgelerinin iştiraki ile 94 ortakla kurulmuş ve yapılan sermaye artırımı ile birlikte 2014 yılından itibaren 118 ortağa ulaşmıştır. BALO, lojistik sektörüne demiryolu ağırlıklı intermodal taşımacılık hizmeti sunmaktadır. BALO, lojistik sektöründe yer alan nakliyeci ve forwarder firmalara blok tren ile yük taşımacılığı hizmetini sunmaya başlamıştır. ${ }^{17}$

Bu iki projenin Balıkesir'de bir araya gelmesiyle; bu kapsamda yurtiçindeki toplama merkezlerinden konteynerlerle alınan yükler tren seferleriyle Anadolu ve Avrupa yakasındaki yük birleştirme merkezlerinde toplanacak ve gideceği şehirlere göre ayrıştırıldıktan sonra Avrupa'daki lojistik kentlere ulaştırılacaktır. Bandırma ilçesi Anadolu yük birleştirme merkezi olacak, burada toplanan yükler Bandırma Limanı'ndan Tekirdağ’a denizyoluyla ulaşarak Avrupa' ya yol alacaktır. Bu projenin hayata geçmesiyle Bandırma ilçesi başta olmak üzere Balıkesir'in stratejik anlamda daha fazla önem kazanacağı öngörülmektedir. ${ }^{18}$

Ayrıca, otomobil, konteyner, sunta, mermer, sentetik malzemeler, kömür, askeri yükler, demir, sanayi ürünleri yanı sıra gıda maddesi olarak et, süt, kuru gıda, içecek maddeleri Balıkesir'deki lojistik köyden yüklenip yurtiçi ve yurtdışına taşınacaktır. Lojistik köy kapsamında konteyner yükleme boşaltma ve stok alanları, gümrüklü sahalar, müşteri ofisleri, otopark, tır parkı, bankalar, restoranlar, oteller, bakım onarım ve yıkama tesisleri, akaryakıt istasyonları, antrepolar, tren teşkil kabul ve sevk yolları yer almaktadır. ${ }^{19}$

\footnotetext{
${ }^{15}$ http://www.gazetegercek.com.tr/haber-detay.asp?H=3026\&Haber=\%91lojistik-koy-2016da-tamamlanacak.

16 http://www.rayhaber.com/2015/balikesir-gokkoy-lojistik-merkezi-hizmete-giriyor/

${ }^{17}$ http://www.balo.tc/hakkimizda, 49

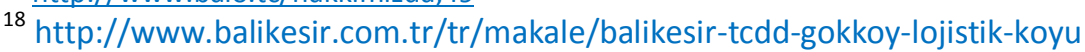

${ }^{19}$ http://www.gmka.org.tr/uploads/downloads/dosya/bolge plani/2014-

2023\%20TR22\%20G\%C3\%BCney\%20Marmara\%20B\%C3\%B6lge\%20Plan\%C4\%B1\%20Tasla\%C4\%9F\%C4\%B1.pdf
} 


\section{Kemalpaşa İzmir Lojistik Köyü}

2011 yılında yapımına başlanılan Kemalpaşa Lojistik Köyü, yapımına devam edilen 6 lojistik köyden biridir. Projesi , AYGM tarafından Elit Proje'ye verilen Kemalpaşa Lojistik Köyü'nün proje içeriği şöyledir; ${ }^{20}$

İzmir Bölgesi'ne tüm yönlerden gelecek yüklerin bir merkezde toplanarak şehre girmesi, olumsuz bir etki yaratmadan tüm dünyaya dağıtılması için otoyol, karayolu ve demiryolunun kesiştiği noktada kurulacak olan Ulusal ve Uluslar arası taşımacılık ve lojistik eşyanın dağıtımı ile ilgili tüm faaliyetlerin muhtelif işletmeler tarafından yapılacağı bütün ulaşım sistemleriyle entegre olarak çalışacak Kemalpaşa Lojistik Köyü inşaatında; çeşitli büyüklüklerde depo ve antrepo, demiryolu peronları, demiryolu yükleme alanları, konteyner açık depolama alanları, genel kargo için depolama alanları, TIR park alanları, otoparklar, araç bakım-servis alanları, sosyal tesisler, yönetim binaları, gümrük binası, itfaiye, ibadethane alanları, rekreasyon alanları, atölyelermanevra-yakıt tankları-yükleme boşaltma alanları ve stok alanları arasındaki demiryolu hatları, iç bağlantı yolları, pis su ve yağmur suyu için tüm altyapı imalatları ve peyzaj çalışmaları planlanmaktadır.

Kemalpaşa Lojistik Köyü hakkındaki genel bilgiler; ${ }^{21}$ Kemalpaşa Lojistik Köyü konumu itibariyle otoyol ve demiryolu bağlantısı bulunmakla birlikte en önemlisi Ege Bölgesinin üretim merkezi olan 320 adet firmanın faaliyet gösterdiği Kemalpaşa Organize Sanayinin bitişiğinde yer almaktadır. Kemalpaşa bölgesinde Organize Sanayi dışında da 100 adet firma faaliyet göstermektedir. Ayrıca ileriye yönelik olarak Çandarlı Limanına demiryolu bağlantısı da mevcuttur. Diğer taraftan Torbalı-Kemalpaşa demiryolu bağlantısı da planlanmakta olup; bu sayede tüm Ege Bölgesinin yüklerinin toplama merkezi Kemalpaşa Lojistik Köy olacaktır. CumaovasıAliağa arasında demiryolu kent içi ulaşıma tahsis edilmesi halinde Denizli, Aydın istikametinden gelen demiryolu yükleri Torbalı-Kemalpaşa-Menemen-Aliağa-Çandarlı güzergahını takip ederek, Çandarlı limanına ulaşacaktır.

- $\quad$ Proje Bedeli: $32.535 .000 \mathrm{TL}$

- Toplam alan: $3.000 .000 \mathrm{~m} 2$

- Kamulaştırma;1.Etap kamulaştırma: 1 milyon m2, 2.Etap kamulaştırma: 1 milyon m2, 3.Etap kamulaştırma: 1 milyon $\mathrm{m} 2$

- İşletme Alanı; Kapalı Toplam Alan : 173.851 m2, Depo Kapalı Alan : 148.752 m2, Açık Depolama Sahası : $570.300 \mathrm{~m} 2$.

- Kapasite; Depolama: 14.211 Konteynır, Açık Sahada: 9090 Konteynır, Antrepo Önü Açık Saha: 5121 Konteynır, Dökme Yük Depo : 6750 m2, Yıllık Yük : 16 milyon ton, Çalışacak Personel Sayısı : 1538 kişi

- Kemalpaşa

Depo \begin{tabular}{ll}
\multicolumn{2}{c}{ lojistik } \\
sahasına & ulaşan \\
sahada & \\
adet & Depo
\end{tabular} köyünde Gümrüklü 8 yapılacak tesisler; $9 \quad$ adet Toplam kapalı alan 173.851 m2'dir.

- Alt yapısının; İhalesi 21 Mart 2012 tarihinde yapıldı. Sözleşmesi 12 Ekim 2012 tarihinde imzalanarak yer teslimi yapıldı. Altyapının 1. Aşamasının 2014 yılının ilk yarısında tamamlanmıştır. Altyapının 2. Aşamasının ihale hazırlıklarına başlanacaktır.

\section{Yenice Mersin Lojistik Köyü}

Yenice Lojistik Köyü'nün yapımı hala devam etmekte olan 6 lojistik köyden biridir. Yenice, Mersin ilçe sınırları içerisindedir. Mersin'de bulunan serbest bölgeye ek olarak lojistik köyünde kurulmasıyla Mersin limanı, Akdeniz ve Ortadoğu'da önemli bir lojistik üssü olacaktır.

Yenice Lojistik Köyü, TCDD’na bağlı Yenice Lojistik Şefliği'nin tam karşı arazisi üzerine kurulacaktır. Kurulacak köyle, şeflik ortak bir çalışma içerisinde olacaktır. 2017 tarihinde hizmete geçmesi planlanmaktadır.

\footnotetext{
${ }^{20}$ http://www.elitp.com/?/detay/projeler/devam eden_projeler/izmir_kemalpasa_lojistik_merkezi/\#

${ }^{21}$ http://www.aygm.gov.tr/BLSM WIYS/DLH/tr/DOKUMAN SOL MENU/Demiryollari/Demiryolu Devam/20130523 15464 4102881 10315.html
} 
Temel ve teknik bilgiler, verilecek hizmetler;

- 4,5 dönüm arazi üzerine kurulması planlanmaktadır.(Toplam alan)

- Şuan 1 adet yükleme- boşaltma rampası oluşturulacaktır. ( $550 \mathrm{~m}$ boyunda, 32m eninde, 1.2m yüksekliğinde).

- Elektronik kantar (220 tona kadar), tarttığı malın resmini çekebilen son teknoloji ürünü.

- 1 portal vinç, beton sahada konteyner elleçleme için kullanılacaktır. $1.2 \mathrm{~km}$ uzunluğunda olacaktır.

- Şuan Yenice Lojistik Şefliği'nde kullanılmakta olan toplamda 10 araç var iken lojistik köyün kurulmasıyla bu araç sayısı 35-40 arasına çıkacaktır.

- Lojistik köyün her tarafı ihata(tel) ile çevrilidir.

- İki ayrı bakım atölyesi oluşturulacaktır; vagon bakım atölyesi ve loko bakım atölyesi olacaktır.

- 14 tane demiryolu olacaktır. 11 ve 13 nolu yollar rampanın yanından yükleme-boşaltma yapmak için kullanılacaktır.

- Denizyolu, demiryolu, karayolu ve havayoluyla bağlantılıdır. Yenice Lojistik Köyü’nün doğusunda Adana Havalimanı, batısında ise Mersin Limanı bulunmaktadır. İ̧ Anadolu'ya giden mallar buradan aktarılmaktadır.

- Katma değerli işlemlerden sadece elleçleme hizmeti verilmektedir.

- Avrupa'daki lojistik köyler gibi otel, restaurant, hastane vb. gibi sosyal hizmetler verilmeyecektir.

- Lojistik Köy'ün etrafında sanayi kuruluşları mevcuttur, buda olumlu yönde etkileyecektir.

- Köy içinde özel iştirak bulunmamaktadır, tamamıyla devlete ait bir projedir.

- Köy için gümrük kurulması planlanmaktadır.

- Köyü'n kendisine ait antrepoları ve depoları olacaktır.

- Yenice Lojistik Şefliği'nde ki toplam idari kadro 10 kişidir. Köyün kurulmasıyla beraber bu sayı artacaktır.

- Şeflik'te çoğunlukla 2 yılık Lojistik Programı mezunları çalışmakta, 4yıllık Lojistik mezunları ise tercih edilmektedir.

- Şeflik'in kendisine ait ayrı bir internet sitesi yoktur. Köy içinde düşünülmemektedir. Şeflik'e ait kurumsal telefon hattıve kurumsal mailleri vardır. yenicelojistiks@tcdd.gov.tr dir.

- KKY Sistemi'ne sahiptirler. Bu bir çeşit TCDD’ye ait ticari işlemleri yaptıkları ortak bir portaldır. Yenice'de yapılan bir ticari işlemi Halkalı'daki memurda görebilmektedir.

- TCDD'nın rakibi yoktur. Vagon ve lokomotif üretimi TCDD’nin tekelindedir.

- Yenice Lojistik Şefliği ISO 9001 onayına sahiptir. Çevre düzenlemesi ile ilgili ISO onaylarına da sahiptir.

- Çevreci politikalar izlenmekte; buharlı trenlerden, dizele geçilmiştir şimdi ise bütün yük ve yolcu taşımasında kullanılan trenleri peyderpey elektrikliye geçirmek amaçlanmaktadır.

- Avrupa'da olduğu gibi Türkiye'de lojistik köyleri düzenleyen ve denetleyen ayrıca bir kurum yoktur. TCDD’nin kendi kontrolörleri vardır, lojistik köyleri dolaşır daha çok teftiş amaçlıdır.

- Yenice Lojistik Şefliği'nde şuan çalışan iş güvenliği uzmanları mevcuttur. Çalışanlara İş güvenliği seminerleri verilmekte ayrıca çalışanlar sınavlara tabi tutulmaktadır. Verilen eğitimlerin bir kısmı internetten bir kısmı ise yüz yüze verilmektedir.

- Yenice'de verilen lojistik hizmetlerindeki müşteri memnuniyetsizliğine sebep olan en önemli neden; hamulenin(malın) zamanında müşterinin eline varmamasıdır.

- Şuan Şeflik'te sadece yurt içine taşıma yapılmakta iken, lojistik köyün kurulmasıyla birlikte yurtdışına da taşıma yapılması planlanmaktadır.

- Şeflik'ten günlük 80-100 vagon arası taşıma yapılmaktadır. Lojistik köyün kurulmasıyla birlikte bu taşıma oranı da $\% 50$ civarında artacaktır.

- Şeflik'ten günlük 1500 ton civarı mal taşınmaktadır, yine lojistik köyün kurulmasıyla bu rakamında \%50 artması planlanmaktadır.

- Yenice'deki lojistik faaliyetlerin ülke ekonomisine kazancı şuan 1,5 milyon yıllık ciro sağlamaktadır, lojistik köyün kurulmasıyla bu rakamın \%50 oranında artacağı düşünülmektedir.

Demiryolu ile Konya bağlantısı lojistik potansiyelini daha da artıracaktır. Projeyle beraber bölgede sinyalizasyon ve demiryollarının kapasite artışı çalışmaları başlamıştır. Yaklaşık 50 milyon liralık yatırımla yükleme boşaltma 
sahaları, rampa, depo, antrepo ve diğer ünitelerin kurulacağı bilinmektedir. Yöre denizyolu, demiryolu, karayolu noktasında bir geçiş noktası konumunda olacaktır. Lojistik köy tamamlandığında, yol, vagon ve lokomotif bakım atölyelerinin buraya taşınacaktır. Proje kapsamında $27 \mathrm{~km}$ ray kullanılarak 13.500 metre yeni demiryolu yapılacaktır. Yenice Lojistik Merkezinde; 8 yola sahip konteyner stok sahaları, 550 metrelik rampa, müşteri stok alanları, 2 otomatik boşaltma alanı, 1 tehlikeli madde boşaltma alanı, gümrüklü eşya ambarı, 13 yola sahip vagon ve lokomotif bakım atölye ve depoları, 1 döner köprü ve 5 yollu, depo, 4 manevra yolu, otopark, yol ve tesisler, bakım şefliği binaları, 1 kantar, iltisak hattı (özel tren yolu hattı) bağlantıları yer alacaktır. Ayrıca mevcut 7 istasyon yolu uzatılarak 11 yola çıkarılacaktır(Elgün, 2011: 55).

Silifke demiryolunun Taşucu/Seka limanına da irtibatlandırılması, otobanın Çeşmeli'den Taşucu'na kadar tesis edilmesi, Konya Karaman Mersin hızı treni, Mersin Ana Konteyner Limanı ve Çukurova Bölgesel Havaalanı gibi doğrudan ya da dolaylı olarak denizcilikle bağlantılı projelerin, bölge ekonomisine ivme kazandıracak yatırımların bir an önce hayata geçirilmesi/tamamlanmasıyla TCDD Tarsus/Yenice lojistik köyü bölgenin parlayan yıldızı olacaktır. ${ }^{22}$

\section{VERI VE YÖNTEM}

Çalışmada, swot(gzft) analizi yöntemi kullanılmıştır. Swot(gzft) analizi; bir projede ya da bir ticari girişimde kurumun, tekniğin, sürecin, durumun veya kişinin güçlü (strengths) ve zayıf (weaknesses) yönlerini belirlemekte, iç ve dış çevreden kaynaklanan fırsat (opportunities) ve tehditleri (threats) saptamak için kullanılan stratejik bir tekniktir. ${ }^{23}$ Yapılan swot(gzft) analizinin konusu, Halkalı Lojistik Köyü’dür. Halkalı Lojistik Köyü'nün güçlü-zayıf yanları verilmiş, tehdit-fırsatları saptanmaya çalışılmıştır. Bilgi edinme yöntemleri; konuyla ilgili internette olan makale ve haberler, yazılmış doktora tezleri, Ulaştırma, Denizcilik ve Haberleşme Bakanlı̆̆ı'na ait belgeler ve bilgiler, TCDD'ye ait belgeler, TCDD ve Bakanlık çalışanlarıyla yapılan yüz yüze ve telefon görüşmeleridir.

\section{BULGULAR VE TARTIŞMA}

\section{HALKALI LOJISTIK KÖYÜ’NÜN SWOT(GZFT) ANALIZI ve TÜRKIYE’DEKi - AVRUPA'DAKI LOJISTIK KÖYLERIN KARŞILAŞTIRILMASI}

Çalışmada analizi yapılmak üzere faaliyete geçmiş olan Halkalı Lojistik Köyü seçilmiştir. Bu köylerin çalışmada kullanılma sebepleri; coğrafi konumları, yük taşıma ve gelişmişlik potansiyelleridir.

\section{Halkalı Lojistik Köyü Hakkında Bilgiler}

1970 yılında İstanbul'da Gümrük Ambar ve Bölge Müdürlüğ̈’ne bağlı olarak kurulmuş, İstanbul ve tüm Trakya bölgesinin gümrük ve demiryolları taşıma işlerini yapan, TCDD Halkalı Lojistik Müdürlüğü haline gelmiş, 2004 yılında Halkalı Lojistik Köyü burada kurulmuştur.

- Halkalı Lojistik Köyü

Adres: Halkalı Lojistik Müdürlüğü Küçükçekmece/İstanbul

Tel: 02126784793

- Halkalı Lojistik Köyü, toplamda, $181.000 \mathrm{~m}^{2}$ alana sahiptir. $47.900 \mathrm{~m}^{2}$ kapalı alan, $60.000 \mathrm{~m}^{2}$ konteyner sahası, $19.000 \mathrm{~m}^{2}$ ihracat alanı, $20.000 \mathrm{~m}^{2}$ ithalat alanı, gerisi yeşil alan ve yol alanıdır.

- Verilen sosyal hizmetler; market, kafe, lokanta, berber, akaryakıt istasyonu, duş.

- Toplam araç sayısı; 3 dolu konteyner vinci, 2 boş konteyner vinci, 16 tane forklift( 2,5 ton- 5ton), 1 tane mobil vinç( 8 ton).

- Köy intermodal taşımacılığa uygundur. Demiryolu ve karayolunda hizmet verilmektedir.

- Toplam idari kadro, 45 kişidir.

- Köyde verilen katma değerli hizmetler; elleçleme, antrepo hizmetleri (etiketleme, ayrıştırma), entegre taşımacılık.

\footnotetext{
22 http://www.lojistikhatti.com/haber/2014/07/mersin-dogu-akdenizin-lojistik-ussu-olacak

23 https://tr.wikipedia.org/wiki/SWOT analizi (Kaynak: (Erişim tarihi:28.04.2016)
} 
- Köy'de toplam 12 tane antrepo vardır her biri 3600m² büyüklügündedir; 2 tanesi TCDD kullanmakta diğer 10 tanesi özel firmalara kiraya verilmektedir. Handerhan A.Ş. bu kiracılardan biridir.

- Köyde kullanılan teknolojiler; kamera ile plaka okuma sistemi, gümrük barkod hizmeti, elektronik kantar. Ayrıca bir Türk firması olan HABERSAN'a yaptırılan, Türkiye'deki toplam maliyeti 10 milyon TL ve sap tabanlı olan KKY (Kurumsal Kaynak Yönetimi) Sistemi.

- Köy'de bürokratik süreç sıfırdır. Yapılan her işlem bir an önce sonlandırılmakta, amaç iş akışını en hızlı şekilde yerine getirmektir.

- Ekonomik dalgalanmalar ve istikrarsızlıklar toplam taşınan yüke etkisi; anında hissedilir. Dolar kuru yükselirse, ithalat durur.

- Köy içinde Halkalı Gar Gümrük Müdürlüğü vardır. Sadece TCDD’nın işlemleri yapılmaktadır. 25 personeli bulunmaktadır. Gümrüğün olumlu etkisi çok büyüktür; iş akışını hızlandırır, zaman kaybını önler.

- Kurum içi çalışanlara sürekli eğitim ve seminerler verilmektedir.

- İşçi kadrosu çoğunlukla sanat okulu mezunu, yönetim kadrosu ise üniversite mezunudur. TCDD’ndaki çalışanların yaş ortalaması yüksektir.

- Köy içinde tedarikçi bir firma yok, "biz bize yetiyoruz" düşüncesi hakim. Sadece özel taşımalarda taşımayı yaptıran tedarikçiyi buluyor. Örneğin; bir firma için yapılan doğalgaz taşımasında, doğalgaz boruları hassas malzeme oldukları için firma kendi getirdiği vinç ile borular vagonlara yerleştirilmiştir.

- $\quad$ Özel şirketler köye sokulmak istenmiyor. TCDD’nin daha çok tekelci bir yapısı mevcuttur. Çünkü iyi bir gelir kaynağı. Fakat TCDD yetişemediği yerlerde özel firmalara izin veriyor.

- Köydeki araçların sürekli yenilenmektedir. Geçen sene köye alınan 1 vincin fiyatı 500.000 Euro'dur.

- Köyün İstanbul'da olmasının olumlu etkileri; İstanbul'un coğrafi konumu, taşımaların ucuza gelmesi (şehir merkezine ne kadar yakın olursa fiyat o kadar düşük olur)

- Köyün İstanbul'da olmasının olumsuz etkileri; Köye günde ortalama 800 adet tırın giriş yapması zaten yoğun olan İstanbul tarifini iyice yoğunlaştırması, egsoz gazının salınımı nedeniyle çevreye verilen zarar.

- Köye en yakın OSB íkitelli'dedir. Köyün etrafında sanayi kuruluşları mevcut değil ama yeni kurulan lojistik köylerde OSB çevrelerine yakınlık dikkat edilen hususlardandır. Örneğin; Manisa Lojistik Köyü.

- Komşu ülkelerdeki savaş köydeki lojistik faaliyetleri etkilememiştir. Çünkü Halkalı Lojistik Köyü'nde Avrupa'da ve Türki Cumhuriyetlere sevkiyat vardır. Genellikle Asya ve Ortadoğu'ya Köseköy'den sevkiyat olmaktadır.

- $\quad A B^{\prime} y e$ uyum sürecinde 1 Mayıs'tan itibaren basitleştirilmeye geçilecek, trenlere yeşil etiket yapıştırılacak bu yeşil etiket ile malın menşesi, taşınan yükün özellikleri vb. özellikleri bilinecek, sınır kapılarında vagonlar beklemeyecek, CIM belgeleri konşimento değeri kazanacak.

- Köy’ün herhangi bir aşamasında kredi kullanılmamış, tamamıyla devlete ait bir yatırım.

- Lojistik köy kavramının gelişmiş olduğu İtalya, Almanya ve İspanya'daki gibi lojistik köyleri denetleyen, düzenleyen, ilgili kararları veren, ayrıca bir kurum yoktur. Ulaştırma, Haberleşme ve Denizcilik Bakanlığı'nca TCDD'ye ait bir alt daire başkanlığınca ilgilenilmektedir. Diğer lojistik köylerde olduğu gibi TCDD'nin kontrolörleri tarafından teftişler yapılır.

- Rekabet yok, TCDD tekel.

- Köy'ün ISO 9001, ISO 14001, ISO4001 onayları yoktur ama Köy'de iş güveliği uygulamaları çok katıdır, altyapı-elektrik sistemlerinin bakım- kontrolleri, çalışanların sağlık ve psikoteknik muayeneleri belirli periyotlarla düzenli olarak yapılmaktadır. Ayrıca kiraya verilen antrepoların özel firmalar tarafından sadece o depoya ait alınan ISO 9001 onayları vardır.

- İşgücü maliyetleri, iç piyasa şartlarına göre oluşturulmaktadır. TCDD, her yıl için yılda bir kere tarife ücretlerini belirler, özel firmaların fiyatlarını dikkate almaz.

- Köy'e en yakın havalimanı; Atatürk Havalimanı (ilişki yok) Köy'e en yakın liman; Ambarlı Limanı (konteyner taşımacılığı)

- Ambarlı Limanı ile Halkalı Lojistik Köy arasında yıllardır fikir aşamasında kalan birleştirme planı vardır. Fakat bu plan liman ile köy arasındaki kot farkından dolayı gerçekleşememektedir.

- Köy'de; günlük 400TEU mal elleçlemesi yapılmaktadır. Ayrıca Köy, 2000 TEU stok kapasitesine sahiptir. 
- Köy'de 2011 yılında; ithalat 8.108 vagon (533.000 ton), ihracat 7.322 vagon (347.000 ton) yük taşınmıştır.

- Halkalı Lojistik Köyü diğer kurulan ve kurulması planlanan lojistik köylerle kıyasladığımız zaman her anlamda ileridedir.

- Ülkemizdeki lojistik köy yapılanmasına baktığımız zaman demiryollarında TCDD tekel durumdadır, özel sektörü işin içine pek sokma taraftarı değildir, zaten özel sektördeki güçlü yatırımcılar, yatııımlarını daha çok tır üzerine yapmıştır fakat $A B$ tırları istememektedir zamanla tırların yerini trenler alacaktır.

- Köy'de herhangi bir şikayet bildirimi yok, aksine herkes çok memnun.

- Köy'de atıl durumda bulunan herhangi bir bina, ekipman yoktur.

- Köy'ün ülke ekonomisine katkısı; yıllık cirosu 3 milyon Euro'dur.

- Diğer lojistik köylerle entegre çalışmaları pek bulunmamaktadır. Fakat müdürlüklerce kendilerine yakın bölgelere teknik yardım yapılmaktadır.

- Köy için yapılması planlanan çalışmalar; altyapı iyileştirilmesi, portal vinç kurulması, pis su ve yağmur suyunun toplanıp arıtılması, internet fiber kollarının kullanılması, yangın sistemleri vb gibi projeler.

- Sipariş alma işlemler etkin olarak yapılmaktadır.

- Diğer lojistik köyler arasında en kaliteli ve en etkin hizmet Halkalı Lojistik Köyü’nde verilmektedir. Türkiye içinde daha kaliteli ve uygun hizmet verilmektedir. Örneğin; Anadolu'daki herhangi bir lojistik köyde 100 ton bir malı 1.500 TL'den aşağı vagona taşıtamazken, Halkalı'da bu işlem 25 Euro'ya yapılmaktadır. Avrupa ülkeleri ile kıyasladığımız zaman ise düşüktür.

- Halkalı́nın parkuru $A B$ bağlantılı olduğundan dolayı sürekli kar etmekte olan ender lojistik köylerdendir.

- Köye ait websitesi yoktur. Kurumsal mail ve telefonları vardır. Örneğin; adsoyad@tcdd.gov.tr

\section{Halkalı Lojistik Köyü SWOT(GZFT) Analizi}

Halkalı Lojistik Köyü'nün Güçlü Yönleri

- Sahip olduğu araç sayısı ve araçların özellikleri.

- Coğrafi konumu. (4.koridor, ìstanbul, Avrupa kıtası)

- Demiryolunun AB ülkelerinde yaygın kullanılması.

- İşgücüne bağlı maliyetin düşüklüğü.

- $A B^{\prime}$ ne uyum sürecinde demiryollarının onarıma alınmış olması, son teknoloji ürünleri kullanılması.

- Sahip olduğu alanın büyüklüğü.

- Verilen katma değerli hizmetler.

- Sürekli kar etmesi.

- Şikayet yerine, memnuniyet geri bildirimleri.

- Çalışan sayısının, ülkemizdeki diğer lojistik köylerdekilerine oranla yüksek olması.

- Ülke ekonomisine katkısı.

- KYY Sistemi gibi SAP destekli son teknolojinin kullanılması.

- Bürokratik süreç, caydırıcı değil teşvik edicidir.

- Sadece köy için kurulmuş olan gümrüğün varlığı.

- Intermodal taşımacılığa uygun olması.

Halkalı Lojistik Köyü’nün Zayıf Yönleri

- Avrupa'daki gibi sistemli bir kurulum planına sahip olmaması.

- Köy'de bilgi teknolojilerinin yeterli düzeyde kullanılamaması.

- Köy içerisinde eczane, hastane, sağlık ocağı vb. kuruluşların olmaması.

- Köy'e ait web sayfasının olmaması.

- TCDD’nin tekel olması ve Köy'de herhangi bir özel firmanın bulunmaması.

- Deniz ve hava taşımacilığına uygun olmaması.

- Küçükçekmece Gölü’nün yanında kurulmuş olmasına rağmen bundan faydalanılmaması.

- ISO onaylarının olmaması. 
- Avrupa'daki köy örneklerine göre her anlamda geride olması.

- Diğer lojistik köylerle entegre halinde olunmaması.

- OSB'lerine uzak olması.

- Mevcut altyapı eksikliği.

- Tanıtım eksikliği.

- Şehir içinde kalması.

- Hinterlandının genişlemeye müsait olmaması.

Halkalı Lojistik Köyü'nün Önündeki Fırsatlar

- Ülke ekonomisinin büyümesi.

- Devletin lojistik sektörünü önemsemesi ve 2023 Hedefleri kapsamında lojistiğin öne çıkarılmasının amaçlanması.

- Lojistik teknolojilerindeki sürekli ve olumlu gelişmeler.

- Deniz taşımasına uygun hale getirilebilir olması.

- Demiryolunun yükselen değer olması.

- Çevre dostu uygulamaların kullanılmaya başlanması.

- TCDD’nın özelleşmeye gitmesi.

Halkalı Lojistik Köyü'nün Önündeki Tehditler

- Küresel krizlerden etkilenmesi.

- $A B^{\prime} y e$ giriş-çıkışlarda araçlarımızın sınırlarda bekletilip, zaman kaybı yaşanması ve sonuçta ortaya çıkabilecek müşteri memnuniyetsizlikleri.

- $\quad$ Artan İstanbul trafiği.

- İstanbul'da ve İstanbul yakınında kurulması planlanan diğer lojistik köyler.

\section{Türkiye'deki - Avrupa'daki Lojistik Köylerin Karşılaştırılması}

Bu bölümde ülkemizdeki ve Avrupa'daki lojistik köyler, çalışmada belirtilen ve verilen bir lojistik köyde olması özellikleri yönünden karşılaştırılacaktır.

Tablo 3: Lojistik Köylerin Karşılaştırılması

\begin{tabular}{|l|l|}
\hline $\begin{array}{l}\text { Türkiye'deki } \\
\text { Lojistik Köyler }\end{array}$ & $\begin{array}{l}\text { Avrupa'daki } \\
\text { Lojistik Köyler }\end{array}$ \\
\hline Toplam alan ortalaması 1.000.000m ${ }^{2 \prime}$ den azdır. & $\begin{array}{l}\text { Toplan alan ortalaması } 1.000 .000 m^{2 \prime}{ }^{2} \text { en } \\
\text { büyüktür. }\end{array}$ \\
\hline Intermodal taşımacılığa elverişlilik düşüktür. & Intermodal taşımacılığa elverişlilik yüksektir. \\
\hline $\begin{array}{l}\text { Uluslararası yol bağlantılara sahiplik oranı } \\
\text { düşüktür. }\end{array}$ & $\begin{array}{l}\text { Uluslararası yol bağlantılara sahiplik oranı } \\
\text { yüksektir. }\end{array}$ \\
\hline $\begin{array}{l}\text { Planlı ve düzenli bir kurulum pek } \\
\text { gözlenememektedir. }\end{array}$ & Planlı ve düzenli bir kurulum gözlenmektedir. \\
\hline Kamusal hizmet veren sosyal alanlar sınırlıdır. & Kamusal hizmet veren sosyal alanlar fazladır. \\
\hline Altyapıları az gelişmiştir. & Altyapıları çok gelişmiştir. \\
\hline Çalışan sayısı 100 kişiden azdır. & Çalışan sayısı 100 kişiden fazladır. \\
\hline Çalışanların kalifiye değildir. & Çalışanlar kalifiyedir. \\
\hline Website yoktur. & Website vardır. \\
\hline Bağlı oldukları ortak bir kuruluş yoktur. & Bağlı oldukları ortak bir kuruluş vardır. \\
\hline
\end{tabular}




\begin{tabular}{|l|l|}
\hline Araç- ekipman sayısı azdır. & Araç-ekipman sayısı fazladır. \\
\hline $\begin{array}{l}\text { Sanayi ç̧relerinde kurulmaya dikkat } \\
\text { edilmemiştir. }\end{array}$ & Sanayi çevrelerinde kurulmaya dikkat edilmiştir. \\
\hline $\begin{array}{l}\text { Sınırı sayıda katma değerli hizmetler } \\
\text { verilmektedir. }\end{array}$ & Katma değerli hizmetlerin tümü verilmektedir. \\
\hline İç suyolu kullanımına önem verilmektedir. & İç suyolu kullanımına önem verilmemektedir. \\
\hline Verilen hizmetin kalitesi düşüktür. & Verilen hizmetin kalitesi yüksektir. \\
\hline Özel firmalar yer almamaktadır. & Özel firmalar yer almaktadır. \\
\hline Taşınan yük miktarı günlük 500TEU'dan azdır. & Taşınan yük miktarı günlük 500TEU'dan çoktur. \\
\hline İş güvenliğine önem verilmektedir. & İş güvenliğine önem verilmektedir. \\
\hline Rekabet yoktur. & Rekabet vardır. \\
\hline Liman ve havalimanları ile entegre değildir. & Liman ve havalimanları ile entegredir. \\
\hline Tanıtım eksikliği vardır. & Tanıtım eksikliği yoktur. \\
\hline $\begin{array}{l}\text { Etkin sipariş alma sürecine rağmen siparişte } \\
\text { gecikmeler sıklıkla yaşanmaktadır. }\end{array}$ & $\begin{array}{l}\text { Etkin sipariş alma sürecine rağmen siparişte } \\
\text { gecikmekler nadiren yaşanmaktadır. }\end{array}$ \\
\hline $\begin{array}{l}\text { Çevre dostu uygulamalara yeni başlanmıştır. } \\
\text { Çevre dostu uygulamaların kullanımı eskiye } \\
\text { dayanmaktadır. }\end{array}$ \\
\hline Tedarikçi firmalar yer almamaktadır. & Tedarikçi firmalar yer almaktadır. \\
\hline Pis su- yağmur suyu toplama depoları yoktur. & Pis su- yağmur suyu toplama depoları vardır. \\
\hline
\end{tabular}

\section{SONUÇ}

Lojistik köylerin sistem yaklaşımı çerçevesinde, tüm alt sistemlerin birlikte düşünülerek planlanması gerekmektedir. Özellikle, lojistik zincirin en önemli noktasını oluşturan limanlarla lojistik köyler arasındaki işbirliği ve entegrasyon, üzerinde durulması gereken önemli konular arasındadır. TCDD’nin lojistik köy çalışmalarında, limanlarla yeterli işbirliğinin yapılmadı̆̆ı, lojistik köylere izole bir tarzda yaklaşıldığı ve bütünleşik planlamadan yoksun olduğu gözlenmektedir. Ayrıca, lojistik köy inşasına başlamadan önce, söz konusu köyün gelişme potansiyeli konusunda algılamalarını değerlendirmek amacıyla sanayiciler, ihracat ve ithalatçılar arasında bir anket çalışmasının yapılması yararlı olacaktır. Diğer taraftan, TCDD ve İstanbul Büyükşehir Belediyesi projeleri arasında yeterli entegrasyon ve sinerjinin sağlanamadığı da gözlenmektedir. Öte yandan, lojistik köy kurma işini, bir moda haline getirip gereksiz yatırımlardan kaçınmak, yer seçimini iyi yapmak gereklidir. Çin'de 2001 yılında lojistik park yatırımları moda haline gelmiş ve yaklaşık 1000 adet lojistik park kurulmuştur, ancak bunların \% 60’ı tamamlandıktan sonra atıl kalmıştır(Kayrak ve Zeybek, 2007: 53).

Türkiye'de lojistik köyler kurulurken özel sektör katılımı arttırılmalı, en çok kullanılan ve en etkin organizasyon yapısı olan özel-kamu sektör işbirliği modeli kullanılmalıdır. Bu arada, lojistik köy kurma isinde, gereksiz yatırımlardan kaçınmalı ve yer seçimi iyi yapılmalıdır.

10. Ulaştırma Şurası'nda dile getirilen;"'lojistik merkezlerin tüm paydaşlar ile birlikte intermodal taşımacılığa uygun olarak yerlerinin tespit edilmesi, "lojistik köy" yada "lojistik merkez"ve benzeri adlarla farklı kamu ve özel, özerk kurumların üzerinde çalıştığı projelere tek bir otorite tarafından standart getirilmesi" hedefi, halen Almanya'daki bir yapılanmanın örnek alınabileceği kanısını doğurmaktadır. Deutsche GVZ-Gesellschaft mbH (DGG): Almanya'daki lojistik köylerin (GVZ) işbirliklerini koordine etmek amacıyla kurulmuş olan çatı 
organizasyon Deutsche GVZ-Gesellschaft mbH (DGG) benzeri bir"koordinatör kurum" aracıllğıyla Türkiye çapındaki tüm "lojistik köy" girişimleri arasında eş güdüm sağlanarak sinerji yaratılabilir( Baran vd., 2008: 53).

Lojistik merkezler işletime açıldığında, Türk Lojistik Sektörüne yıllık yaklaşık 40 milyar \$ katkı sağlaması, ilave 26 milyon ton taşıma üretmesi, 8 milyon $\mathrm{m} 2$ konteyner stok ve elleçleme sahası kazandırması beklenmektedir(TOBB, 2012: 74). TCDD özelleşerek Türkiye'deki lojistik sektörünün ve lojistik köylerin önü açılacaktır. Ülkemizdeki lojistik sektörünün ve lojistik köylerin sahip olduğu yüksek getiri potansiyeli ile lojistik köylerin yaygınlaştırılması hem lojistik sektörünün hem de ekonominin büyümesinde faydalı olacaktır.

\section{KAYNAKLAR}

A pan-European Perspective, 2005, Industrial Logistics Propertyin the future.

Acar Z. ve Gürol, P. 2013, " Türkiye' de Lojistik Yazınının Tarihsel Gelişimi", İşletme Araştırmaları Dergisi 5/3 289-312 (Makale) s.291.

AYDıN, G. ve ÖĞÜT, S. 2008, “Lojistik Köy Nedir?”, 2. Uluslararası Demiryolu Sempozyumu, Demiryolu Fuarı Bildiriler Kitabı, TCDD, İstanbul, s. 2-3.

Baki, B. 2004, "Lojistik Yönetimi ve Lojistik Sektör Analizi", Trabzon.

Bamyacı, M. 2008, "Modern Lojistik Yönetimi: Organize Lojistik Bölgeleri Için Bir Yer Seçim Modeli" (Doktora Tezi). İstanbul Üniversitesi, Fen Bilimleri Entitüsü, İstanbul. S.80.

BARAN, H., ALEV, A. Ve SARGIN, B. 2008, “Avrupa'daki Önemli Lojistik Köyler Raporu”, Çalışma Raporu, İzmir Ticaret Odası, İzmir. S.2-3.

B.K.K.A(Batı Karadeniz Kalkınma Ajansı, 2013, TR 81 Düzey 2 Bölgesi Ulaşım ve Lojistik Master Planı, TOBB Üniversitesi, Aralık, s.24.

Canıtez M. ve Güçlü T. 2005, "İthalat ve ihracatta Lojistik, Uygulamalı İthalat ihracat ve Dokümantasyon",Ankara: Gazi Kitabevi, s.153.

DEMIROĞLU Ş. ve ELEREN A. 2014, "küresel lojistik köyleri ve türkiye'de kurulması planlanan lojistik köy bölgelerinin çkkv yöntemleriyle belirlenmesi" Dumlupınar Üniversitesi Sosyal Bilimler Dergisi 42. Sayı Ekim, s.190.

Dikmenli,O. 2008, "AB Üyelik Sürecinde Türk Lojistik Sektörünü Etkileyen Faktörler ve Bir Araştırma", İstanbul Üniversitesi, SBE, Yayımlanmamış Doktora Tezi, İstanbul, s.86.

D.A.K.A.Doğu Akdeniz Kalkınma Ajansı Lojistik Sektör Raporu, 2014,Hatay, K.maraş, Osmaniye s.5.

Elgün,M.N. 2011, "Uluslar arası Taşıma ve Ticarette Lojistik Köylerin Sağladığı Rekabet Avantajları: Bir Model Önerisi” Yayımlanmamış Doktora Tezi, Afyon Üniversitesi SBE, Afyon Karahisar s.55.

Erdal,M. ve Çancı, M. 2012, "Üç Kıtanın Geçiş Noktası: Türkiye-Lojistik Fırsatlar ve Sorunlar", UTA LOJiSTiK, Yıl:8,Sayı:9, Eylül.

Gilberto, G. 2005, "Freight village - Directions for use, Europlatforms: The European Association of Freight Villages", Kiev. S.2.

GILBERTO G. 2006, "Best practices in Europe: the example of freight villages; PRESIDENT OF EUROPLATFORMS The European Association of freight villages", Thessaloniki, November.

Görgülü, H. 2012, "Lojistik Köyler ve Konya Uygulaması" Bahçeşehir Üniversitesi, FBE, Yayımlanmamış Yüksek Lisan Tezi, İstanbul, S.6

GÜN, D. 2012, "Küresel düzeyde Sürdürülebilir Lojistik Yönetimi İçin Lojistik Köylere Paradigmal Bir Yaklaşım ve İskenderun Lojistik Köy Projesi", Ulusal Lojistik ve Tedarik Zinciri Kongresi, Aybil Yayınları, Konya, s.389.

IŞIKHAN F. 2011, “İntermodal Taşımacılık ve Lojistik Köylerin AB ve Türkiye Uygulamaları”, YÜKSEK LISANS TEZi TRAFIK PLANLAMASI VE UYGULAMASI ANABILIMDALI, GAZI ÜNIVERSITESI FEN BiLIMLERI ENSTITÜSÜ, ANKARA, s.81.

iZTO, 2008, Lojistik Köyler Raporu, s.3, 46.

Karadeniz, V. ve Akpınar, E. 2011, Türkiye'de Lojistik Uygulamaları ve Yeni Bir Lojistik Köy Önerisi, Marmara Coğrafya Dergisi, (Erzincan üni Eğiti Fak.)Sayı:23, S. 49-71 isTANBUL - ISSN:1303-2429 s.56.

KAYABAŞı, A. 2010, "Rekabet Gücü Perspektifinde Lojistik Faaliyetlerde Performans Geliştirme", İstanbul Ticaret Odası Yayınları, İstanbul. S.86.

Kaynak, M. ve Zeybek, H. 2007, “Intermodal Terminallerin Gelişiminde Lojistik Merkezler, Dağıtım Parkları ve Türkiye’deki Durum”, Gazi Üniversitesi iliBF Dergisi 9/2, S.53.

Laitio, K. ve H. Perala. 2004, "NeLoc, Summary of Activities and Results of The Neloc Project", Center For Maritime Studies, University of Turku. S.6.

Shahryar A. ve Moayedfar, R. 2008, "The Feasibility Study On Creation of Freight Village In Hormozgan Province", Transport, 23(2), 2 , s.167. 
Schacke, I. (2001). Freight logistics and transport systems in europe, European Council Of Applied Sciences And Engineering Report, Paris, S.16-20.

Tanyaş, M. 2004, "Lojistik ve Tedarik Zinciri Yönetimi", Ders Notları, I.T.Ü. Endüstri Mühendisliği Bölümü

TCDD, Lojistik Merkezler.

Tanyaş, M. 2010, "Kentsel Lojistik", Bölüm 4, Lojistik Köyler.

Tanyaş, M. ve Hazır K.(Editörler) 2011, "Temel Lojistik Kavramlar(Lojistiğe Giriş)", Birinci Baskı, Tarsus, Çağ Üniversitesi. s.7, $242-246$.

TiMUR N. 1988, Sanayi İşletmelerinde Lojistik Faaliyetlerin Organizasyonu,Anadolu Üniversitesi Yayınları No: 266 ,íktisadi ve İdari Bilimler Fakültesi Yayın No :58, Eskişehir s.9

TOBB, 2014, Ekonomik Rapor, 71. Genel Kurul, Yayın No: 2015/253, Özyurt Matbaacılık, Ankara, S.127

TOBB, 2012, "Türkiye Ulaştırma ve Lojistik Meclisi Sektör Raporu 2011", TOBB Yayınları, Yayın Sıra No:2012/165, Ankara, S.74.

TOBB, 2012, "VI. Türkiye Sektörel Ekonomi Şurası [Turkey's Sectoral Economic Council]". Ankara, s.361-366.

Tsamboulas, D. ve Dimitropoulos, j. 1999 "Appraisal of investments in European nodal centres for goods: a comparative analysis", Transportation, 33, England, S.142.

"Türkiye Ulaştırma ve Lojistik 2011 Sektör Raporu"(2012) , TOBB Yayınları, Haziran, Ankara, s.1-2.

TÜSIAD, 2012, "Türkiye'de Dış Ticaret Lojistik Süreçleri: Maliyet ve Rekabet Unsurları", Yayın no: TÜSIAD-T/2012-03/526, Sis Matbaacılık, Istanbul, Mart, S.18.

Yılmaz G.A. 2015, "2008 Küresel Krizi ve Lojistik Sektörü Üzerine Etkileri", Yayımlanmamış Yüksek Lisans Tezi, Uludağ Üniversitesi Sosyal Bilimler Enstitüsü, Bursa, s.52

http://www.aygm.gov.tr/BLSM WIYS/DLH/tr/DOKUMAN SOL_MENU/Demiryollari/Demiryolu Devam/20130523 154644 10288 11031 5.html, Erişim Tarihi: 11.04.2016.

http://www.balikesir.com.tr/tr/makale/balikesir-tcdd-gokkoy-lojistik-koyu, Erişim Tarihi: 31.03.2016.

http://www.denizticaretgazetesi.org/turkiyenin lojistik koyleri haber8059.html, Erişim Tarihi 11.04.2016

http://www.izto.org.tr/portals/0/lojistik merkez kavrami ve italyadaki lojistik merkezler.pdf, Erişim Tarihi: 07.04.2016.

http://www.balo.tc/hakkimizda,49, Erişim Tarihi: 11.04.2016

http://www.elitp.com/?/detay/projeler/devam eden projeler/izmir kemalpasa lojistik merkezi/\#, Erişim Tarihi: 12.04.2016.

http://europe-re.com/report/view/41782/a-new-logistics-real-estate-landscape-the-impact-of-multi-channel-retail-on-logistics-ill, Erişim Tarihi 07.01.2016.

http://www.gazetegercek.com.tr/haber-detay.asp?H=3026\&Haber=\%91lojistik-koy-2016da-tamamlanacak, Erişim Tarihi:11.04.2016.

http://www.gmka.org.tr/uploads/downloads/dosya/bolge plani/20142023\%20TR22\%20G\%C3\%BCney\%20Marmara\%20B\%C3\%B6lge\%20Plan\%C4\%B1\%20Tasla\%C4\%9F\%C4\%B1.pdf, Erişim Tarihi: 03.04.2016.

http://www.lojistikhatti.com/haber/2014/07/mersin-dogu-akdenizin-lojistik-ussu-olacak, Erişim Tarihi: 12.04.2016.

http://www.lojistikci.com/?p=3824, Erişim Tarihi: 05.01.2016.

http://www.promobologna.it/binary/promo bologna/brochure/22 2 NEW INTERPORTO.1208247963.pdf, Erişim Tarihi: 07.04.2016.

https://tr.wikipedia.org/wiki/SWOT analizi, Erişim tarihi:28.04.2016.

http://www.rayhaber.com/2015/balikesir-gokkoy-lojistik-merkezi-hizmete-giriyor/, 11.04.2016.

http://www.udhb.gov.tr/images/faaliyet/c19d85352980eaf.pdf, Erişim Tarihi: 11.04.2016.

http://www.invest.gov.tr/tr-tr/sectors/Pages/TransportationAndLogistics.aspx, Erişim Tarihi; 03.03.2016.

http://www.und.org.tr, Erişim tarihi 26.12.2015.

ACI(2013), Cargo Traffic 2013 FINAL (Annual), http://www.aci.aero/Data-Centre/Annual-Traffic-Data/Cargo/2013-final, Erişim tarihi: 06.01.2016.

AT Kearney, http://www.atkearneypas.com/knowledge/publications/2010/China 2015.pdf, Erişim Tarihi:07.01.2016.

Uysal, O. https://tr.railturkey.org/2014/01/27/2014-butcesinde-yuk-tasimaciligi-projeleri/, Erişim tarihi: 11.04.2016. 